\title{
Braverman, o Estado e a "administração consensual"
}

\author{
Braverman, State, and "consensual administration" \\ Claudio Gurgel ${ }^{1}$
}

\section{Resumo}

Este artigo tem por objetivo discutir o papel do Estado, no plano da economia capitalista, a partir do capítulo sobre esse tema, do livro Trabalho e capital monopolista, de Harry Braverman. Inicialmente, o texto analisa e atualiza os quatro ângulos ou dimensões apontadas por Braverman, quanto ao papel do Estado: o consumo, a internacionalização do capital, a assistência social e a prestação de serviços básicos. Em seguida, identifica outras dimensões que não foram destacadas pelo teórico norte-americano e, então, avança em direção à contemporaneidade, levantando três novas funções que emergiram da crise geral dos anos 1970 e 1980 e da crise aberta em 2008. O estudo é realizado por meio de pesquisa bibliográfica e da consulta a documentos técnicos, além de periódicos. A conclusão é de que o papel do Estado em face do capitalismo contemporâneo elevou-se a um grau em que as fronteiras entre o público e o privado estão desaparecendo sob um novo caráter do Estado. Esse novo caráter, marcado pela estreita vinculação entre os governos e as empresas, inclui o abandono da distinção entre valor público e valor privado, impulsiona a transformação de todos os valores em mercadoria e torna obsoleto o debate sobre intervenção e tamanho do Estado.

Palavras-chave: Estado. Capital Monopolista. Administração Pública.

\begin{abstract}
This article aims to discuss the State's role, in the sphere of capitalist economy, by means of the chapter addressing this theme, from the book Labor and monopoly capital, by Harry Braverman. First, the text analyzes and updates the four angles or dimensions pointed out by Braverman, regarding the State's role: consumption, internationalization of capital, social security, and provision of basic services. Subsequently, it identifies other dimensions that were not highlighted by the American theorist and, then, advances towards contemporaneity, raising three new functions that emerged from the general crisis of the 1970s and 1980s and from the crisis that began in 2008. The study is conducted through bibliographic research and referral to technical documents, in addition to journals. The conclusion is that the State's role in face of the contemporary capitalism rose to a degree where the boundaries between public and private have been disappearing under a new State's nature. This new nature, marked by close ties between governments and companies, includes abandoning the distinction between public and private value, it drives the transformation of all values on commodity and makes obsolete the debate about intervention and the State's size.
\end{abstract}

Keywords: State. Monopoly Capital. Public Administration.

Artigo submetido em 26 de fevereiro de 2014 e aceito para publicação em 21 de agosto de 2014.

DOI: http://dx.doi.org/10.1590/1679-395117005

Economista, doutor em Educação, mestre em Administração Pública, mestre em Ciência Política; professor Associado do Departamento de Administração da Universidade Federal Fluminense. Endereço: Rua Mário Santos Braga, 30 - $7^{\circ}$ andar - Sala 722 , CEP 24020-140, Niterói-RJ, Brasil. E-mail: crmgurgel@hotmail.com 


\section{Introdução}

A leitura de Trabalho e capital monopolista, de Harry Braverman, é absolutamente necessária para quem trabalha na área das ciências sociais e, particularmente, para os que estudam a gestão do trabalho no modo de produção capitalista.

Foi com essa consciência de necessidade que incluímos Braverman como referência. Digamos melhor: a referência principal à compreensão de como se construiu essa figura contraditória da gerência no mundo empresarial e como ela se colocou diante do desenvolvimento capitalista. Ou, ainda, como evoluiu o trabalho nesse desenvolvimento, na relação com a ciência e a técnica e como os trabalhadores assalariados foram se diversificando, ainda que sua relação social de produção guardasse características fundamentais que continuaram a nos permitir falar de classes e diferenças de classes.

Diz Braverman que seu livro "trata da classe trabalhadora como classe em si mesma, e não como classe para si mesma", determinando-se à "limitação auto imposta ao conteúdo 'objetivo' de classe" (BRAVERMAN, 1977, p. 33-34). Não há dúvida de que ele faz esse esforço. Entretanto, também não há dúvida de que sua riqueza instrumental de análise, paradoxalmente, não lhe permitiu obter sucesso nesse aspecto. A leitura dos fenômenos pela óptica marxista, como ele a faz, envolve tantas dimensões de conhecimento que inevitavelmente desliza, se assim é possível dizer, para os campos da filosofia e da política. Ele, portanto, vai além do que supôs se "autoimpor".

Seu livro constitui uma análise ampla, sem comedimentos metodológicos que o impedissem de debater os muitos aspectos do trabalho, inclusive aqueles que tocam as contradições de classe e o embate constante nos planos econômico, teórico e político.

É nesta última dimensão, a dimensão política, que ali, em Trabalho e capital monopolista, encontra-se um capítulo sobre $O$ papel do Estado. Nele, o $14^{\circ}$ capítulo, Braverman faz uma abordagem genérica sobre o Estado, em linhas iniciais, mas a seguir procura materializar essa abordagem, pontuando os aspectos que considera importantes como identificações práticas da função do Estado no âmbito da economia política.

O contato com esse capítulo chama a atenção, inicialmente, pelo fato de estar ali o mais sintético dos capítulos do livro, contido, no duplo sentido da palavra, em cinco páginas.

Neste artigo, propomos uma revisão do que nos diz Braverman sobre o papel do Estado no plano do trabalho e do capital monopolista e examinamos a quantidade de mudanças operadas ao longo dos quarenta anos que nos separam do lançamento de sua principal obra, que ora é homenageada nesta edição temática do Cadernos EBAPE.BR.

Para isso, vamos destacar, evidentemente, os pontos principais do capítulo que, a despeito do tamanho, é, como frequentemente ocorre com os autores fundamentais, rico em nuances. Essas nuances devem ser valorizadas - e procuramos fazer isso - para tentar extrair o máximo de consequências teóricas do que nos oferece o autor.

A seguir, vamos colocar a questão sobre o que podemos dizer que Braverman não passou em revista ou não viu. Não viu porque a história não tinha posto em cena ou simplesmente não viu porque nossos sentidos, às vezes, falham ou, ainda, porque não olhou com atenção, por considerar pouco relevante para os objetivos que teve em sua obra.

Nesse sentido, visitamos as fontes mais recentes dos acontecimentos. Isso significa que, em alguns episódios, trabalhamos com fontes como jornais e documentos. Como, porém, precisamos, em certos momentos, verticalizar a investigação, também consultamos os fundamentos que explicariam esses fatos ou essas interpretações. Isso pudemos encontrar, principalmente, nos pensadores modernos, razão pela qual também recorremos a eles. 
Em respeito ao autor, nas apreciações críticas que eventualmente fazemos, tomamos principalmente os referenciais marxistas para efeito de análise. Não seria razoável olhar Braverman e seu texto com lentes diferentes, em particular quando de algum reparo. Estamos dizendo, portanto, que nossa pesquisa bibliográfica, para efeito de aduzir informações e dados, não tem uma referência específica, mas a abordagem teórica do texto de Braverman é realizada tomando a própria referência fundamental do autor.

É com essa caracterização que podemos localizar o objetivo deste artigo e o modo como pretendemos fazêlo, nos termos básicos que os procedimentos metodológicos exigem frequentemente.

Entretanto, é quase uma necessidade do autor, comum em todo esforço de pesquisa e produção intelectual, a pretensão que vai além da descrição funcional de onde se deseja chegar e por quais caminhos. Nesse sentido, vale acrescentar que este artigo almeja alcançar resultados que possam, de fato, contribuir da melhor maneira com a homenagem ao autor e sua obra: seguir seus passos e procurar andar um pouco mais.

Em outras palavras, trata-se de, no espírito hegeliano do desenvolvimento sem fim, tentar levar adiante, a partir de Braverman, a reflexão, ainda que nos limites de um artigo, sobre o papel do Estado no capitalismo monopolista.

\section{O Papel do Estado: O que Braverman Viu}

Em sentido geral, Braverman entende o Estado nos mesmos termos que Marx e Engels o definiram primordialmente: como um comitê político a serviço da classe dominante. "O emprego do poder do Estado para estimular o desenvolvimento do capitalismo não é um fenômeno novo, peculiar à fase monopolista [...]. O governo dos países capitalistas desempenhou esse papel desde os inícios do capitalismo" (BRAVERMAN, 1977, p. 242).

Sabemos que o papel do Estado no nascimento, crescimento e sobrevivência do capitalismo observa um crescendo que vai do menos que nada, parodiando Zizek/Hegel, até o intervencionismo econômico. Menos que nada porque, em rigor, a burguesia encontrou, em seu início, mais dificuldades que facilidades por parte do Estado, cujas barreiras alfandegárias e outras imposições extorsivas inspiraram as célebres consignas do "laissez-faire, laissez-passê". Não só o Estado não ajudava, mas restringia os movimentos do fazer burguês, que eles pretendiam, tal qual hoje alguns ainda pretendem, sem regulação. Além disso, restringia os movimentos da circulação de mercadorias, fundamental para que se cumprisse o ciclo necessário (D-M-D') ao lucro e à acumulação.

O papel do Estado nesse momento não representava o apoio fundamental que se supõe. Em rigor, o modo de produção vai se desenvolver à força de seus recursos econômicos e será sustentado pelo poder que isso vai representar nas relações sociais de produção e nas relações sociais, em sentido amplo. É essa situação que vai fazer com que Marx e Engels, em variadas obras, se refiram a um Estado que depende do capital e não a um capital que dependa do Estado. Segundo eles, "a política já dependia a tal ponto do comércio no século XVIII, que quando o Estado francês, por exemplo, pretendeu contrair um empréstimo aos holandeses, foi necessário que um particular servisse de fiador" (MARX e ENGELS, s/d, p. 181).

Como observam em outra passagem suficientemente clara:

Chegamos forçosamente, ao se desenvolver a produção e a troca, ao atual regime capitalista de produção, ao monopólio dos meios de produção [...] à degradação de outra classe [...] proletários despojados [...] E todo esse processo se explica por causas puramente econômicas, sem necessidade de se recorrer ao argumento do roubo, nem ao da violência, nem ao Estado, nem mesmo a qualquer outra intromissão de caráter político (MARX e ENGELS, 1982, p. 141). 
Mais tarde, mais de um século depois, Hobsbawn, historiando os primórdios do capitalismo, dirá que "as exigências específicas dos homens de negócio podiam encontrar a resistência de outros interesses estabelecidos [...] No geral, todavia, o dinheiro não só falava como governava" (HOBSBAWN, 1994, p. 23). Para não deixar dúvida, acrescenta na mesma linha: "Tudo que os industriais precisavam para serem aceitos entre os governantes da sociedade era bastante dinheiro""2.

O desenvolvimento do capitalismo, entretanto, não dispensou o Estado.

Logo se revelou que a capacidade revolucionária do capitalismo não o levaria a, de fato, promover a igualdade, a liberdade e a fraternidade. Seu projeto, diferentemente, levou ao aumento da exploração do trabalho e a relações sociais de produção cada vez mais conflituosas. A constância dos embates e lutas econômicas e políticas foi tornando o Estado necessário à reprodução do sistema, tanto quanto seus recursos econômicos e técnicos de produção. É esse Estado que vai ser conquistado, como parte do desenvolvimento da economia capitalista. É o crescimento do papel econômico do sistema que o vai levar ao poder político. Tal qual o interesse pelo poder político decorre da necessidade de garantir condições legais de reprodução do sistema. Essa dialética é que faz com que os dois pensadores alemães digam que "o Estado é um comitê para gerir os negócios comuns de toda a classe burguesa” (MARX e ENGELS, 1982, p. 23).

O passar dos anos não foi diminuindo esse papel, antes o contrário. Crescentemente, o Estado foi se fazendo importante na reprodução, evoluindo de sua função de Estado gendarme, para o Estado social e, a seguir, para o Estado intervencionista, "de origem econômica" (GRAMSCI, 1968; ESPING-ANDERSEN, 1991; FIORI, 1995; POLANYI, 1980).

Esse processo foi se efetivando como um desenvolvimento cumulativo, que nos permitiria falar de papéis do Estado, uma vez que o Estado burguês não abre mão de seus significados anteriores. Ele se tornou gendarme, social e intervencionista, constituindo um todo que mais tarde permitiria a Gramsci, em visualização genial, construir sua percepção e conceito de Estado ampliado.

Portanto, esse sentido evolutivo e também cumulativo do Estado, ao mesmo tempo que dá razão a Braverman, quando diz que "o emprego do poder do Estado para estimular o desenvolvimento do capitalismo não é um fenômeno novo", reforça a necessidade de considerá-lo um fenômeno que se renova, no sentido mais rico da expressão. Um fenômeno que tem uma história, um devir, que, por seu turno, revela a crescente insustentabilidade autárquica do sistema a que pertence e a que serve. Um fenômeno que vai transformando esse sistema em algo estranho aos seus fundamentos e origens.

${ }^{2}$ Em passagem de $O$ Capital, Marx reafirma sua avaliação de que o caráter econômico do capitalismo é o essencial do seu poder, mas indica a existência de um apelo à força do Estado para a efetivação da acumulação primitiva. Ainda assim, permito-me dizer que o processo de acumulação primitiva se constrói no âmbito do poder feudal. O corte umbilical se dá gradativamente e a burguesia cedo se coloca em rota de colisão com as exigências do Estado. Na citação de Marx a que passamos, e que nos foi indicada por um intelectual marxista, fica evidente que o pensador está reapresentando a mesma análise que citamos neste texto, ainda que, é absolutamente verdade, atribua papel ao Estado na acumulação primitiva. Vejamos a citação: "Não basta que as condições de trabalho apareçam num polo como capital e no outro polo, pessoas que nada têm para vender a não ser sua força de trabalho. Não basta também forçarem-nas a se venderem voluntariamente. No desenvolvimento da produção capitalista, desenvolve-se uma classe de trabalhadores que, por educação, tradição, costume, reconhece as exigências daquele modo de produção como leis naturais evidentes. A organização do processo capitalista de produção plenamente constituído quebra toda a resistência, a constante produção de uma superpopulação mantém a lei da oferta e da procura de trabalho e, portanto, o salário em trilhos adequados às necessidades de valorização do capital, e a muda coação das condições econômicas sela o domínio do capitalista sobre o trabalhador. Violência extraeconômica direta é ainda, é verdade, empregada, mas apenas excepcionalmente. Para o curso usual das coisas, o trabalhador pode ser confiado às 'leis naturais da produção', isto é, à sua dependência do capital que se origina das próprias condições de produção, e por elas é garantida e perpetuada. Outro era o caso durante a gênese histórica da produção capitalista. A burguesia nascente precisa e emprega a força do Estado para 'regular' o salário, isto é, para comprimi-lo dentro dos limites convenientes à extração de mais-valor, para prolongar a jornada de trabalho e manter o próprio trabalhador num grau normal de dependência. Esse é um momento essencial da assim chamada acumulação primitiva" (MARX, 1985, p. 277). 
Concretamente, Braverman viu, no início dos anos 1970, um Estado que, em relação ao trabalho e ao capital monopolista, cumpria seu papel em quatro dimensões: a dimensão do consumo; a dimensão internacional; a dimensão assistencial; e a dimensão dos serviços públicos.

A dimensão do consumo vai ao encontro do repetitivo problema do excedente de produção, "um excedente econômico maior do que o que pode absorver" o mercado. (BRAVERMAN, 1977, p. 243). Essa situação crítica é uma consequência da assimetria entre a distribuição da riqueza e a produtividade crescente do trabalho. À medida que a produção cresce, ao toque dos antigos e novos métodos, além da adoção de tecnologia avançada, os salários e outras formas de remuneração do trabalho não crescem de modo a habilitar os trabalhadores ao consumo daqueles bens. Igualmente, em face dos métodos e tecnologias produtivistas, o emprego não se expande a ponto de incluir as camadas marginais à economia nesse mercado consumidor. A falta de demanda efetiva dos consumidores privados leva à restrição da produção, ao desemprego, com todas as suas consequências realimentadoras da falta de demanda efetiva, em espiral negativo. É nesse quadro que a presença do Estado viabiliza sua dimensão de consumo, importantíssima para manter, às vezes elevar, ou pelo menos compensar a ausência dos consumidores privados. Como diz Braverman (1977, p. 243), "os gastos governamentais, na medida em que são ampliados, preencherão esta lacuna".

Esse papel, tem razão Braverman, vai se fazer reconhecido como uma necessidade do sistema a partir da Grande Depressão nos anos 1930, quando se recorre ao programa intervencionista do New Deal, em que o Estado, nos Estados Unidos sob Franklin Roosevelt, exerce-o muito bem. Um pouco mais tarde, quando ainda se tentava sair da depressão, em 1935, Kalecki publica, na revista Econometria, sua teoria sobre a microdinâmica dos ciclos de negócio e, em 1936, Keynes lança a Teoria geral do emprego, do juro e da moeda, ambos questionando a capacidade autorreguladora do mercado e oferecendo os fundamentos teóricos do intervencionismo estatal, com vistas a reequilibrar a demanda efetiva (KALECKI, 1935; KEYNES, 1964).

A dimensão do consumo foi extensivamente tomando conta do mundo econômico e tornou-se uma prática de tamanho variado nos países capitalistas. A despesa pública de alguns países chegou a taxas superiores a 50\% do seu produto interno bruto (PIB); outros se mantiveram na casa dos $30 \%$, mas nenhum deles retornou aos níveis anteriores à Segunda Guerra Mundial. Inicialmente, essa prática de ampliação do consumo do Estado se viabilizava com os desafios keynesianos - obter e garantir o pleno emprego, investir em infraestrutura e monitorar as propensões a poupar e a consumir. Entretanto, logo após a Segunda Guerra Mundial, com o advento e expansão mundial do Welfare State, as políticas sociais incrementadas ampliaram o consumo público intensamente. Gastos com educação, saúde, transporte, habitação e até alimentação elevaram consideravelmente o orçamento do Estado voltado ao consumo de bens e serviços.

O segundo destaque de Braverman para o Estado é o que denominamos dimensão internacional.

Nessa dimensão, ele vê o Estado apoiando o capitalismo em sua concorrência econômica por mercados, por fontes de matéria-prima e por investimentos. Essa concorrência chegaria a paroxismos que levaram (e levam) a "confrontos militares entre países capitalistas" (BRAVERMAN, 1977, p. 243). Além disso, os movimentos revolucionários ou libertários, tais quais as guerras de libertação, também demandam a presença dos países centrais e até de países periféricos (veja-se o caso do Brasil no Haiti), quando se dão ao custoso trabalho de "policiar a estrutura mundial do capitalismo". Os gastos militares, cujas estatísticas são assustadoras, levaram Baran e Sweezzy (1982) a atribuir o crescimento econômico dos EUA no pós-guerra a essa atividade de policiamento mundial. Os números desses autores, conhecidos por Braverman, são impressionantes. Não há dúvida de que o volume das demandas militares e os orçamentos para custeá-lo são perfeitamente capazes de consumir muitos excedentes e mobilizar muitos recursos financeiros do Estado. Isso fica evidente, como também é evidente a evolução desses gastos, ainda que se possa discutir a tese que aqueles autores querem sustentar, a qual reduz o sucesso da economia americana aos investimentos estatais na economia de guerra. 
Braverman publicou a primeira edição de Trabalho e capital monopolista em 1974. Ele já presenciara a Guerra da Coreia, primeiro grande conflito regional do pós-guerra, e a Guerra do Vietnã, que significou US\$ 749 bilhões ao contribuinte dos Estados Unidos. Entretanto, após a publicação de sua obra, os Estados Unidos desencadeariam mais três grandes conflitos regionais: a Guerra do Golfo, de 1990 a 1991, na qual os gastos militares foram a US\$ 103 bilhões; a Guerra do Iraque, de 2003 a 2011, que consumiu US\$ 863 bilhões; e a Guerra do Afeganistão, iniciada em 2001, e, em rigor, ainda não encerrada, onde foram investidos, até 2009, US\$ 438 bilhões (DAGGETT, 2010).

A supressão da União Soviética e a instalação do que se poderia compreender como a superação da Guerra Fria - cujos efeitos, como percebemos, foram várias guerras quentes regionais - não significou, portanto, a desmobilização do xerife mundial. O gráfico dos gastos militares dos Estados Unidos, de 1988 a 2010, mostra como as novas demandas de guerra reativaram o papel do Estado naquele país, nesse aspecto.

Gráfico 1

Gastos militares dos Estados Unidos (1988-2010)

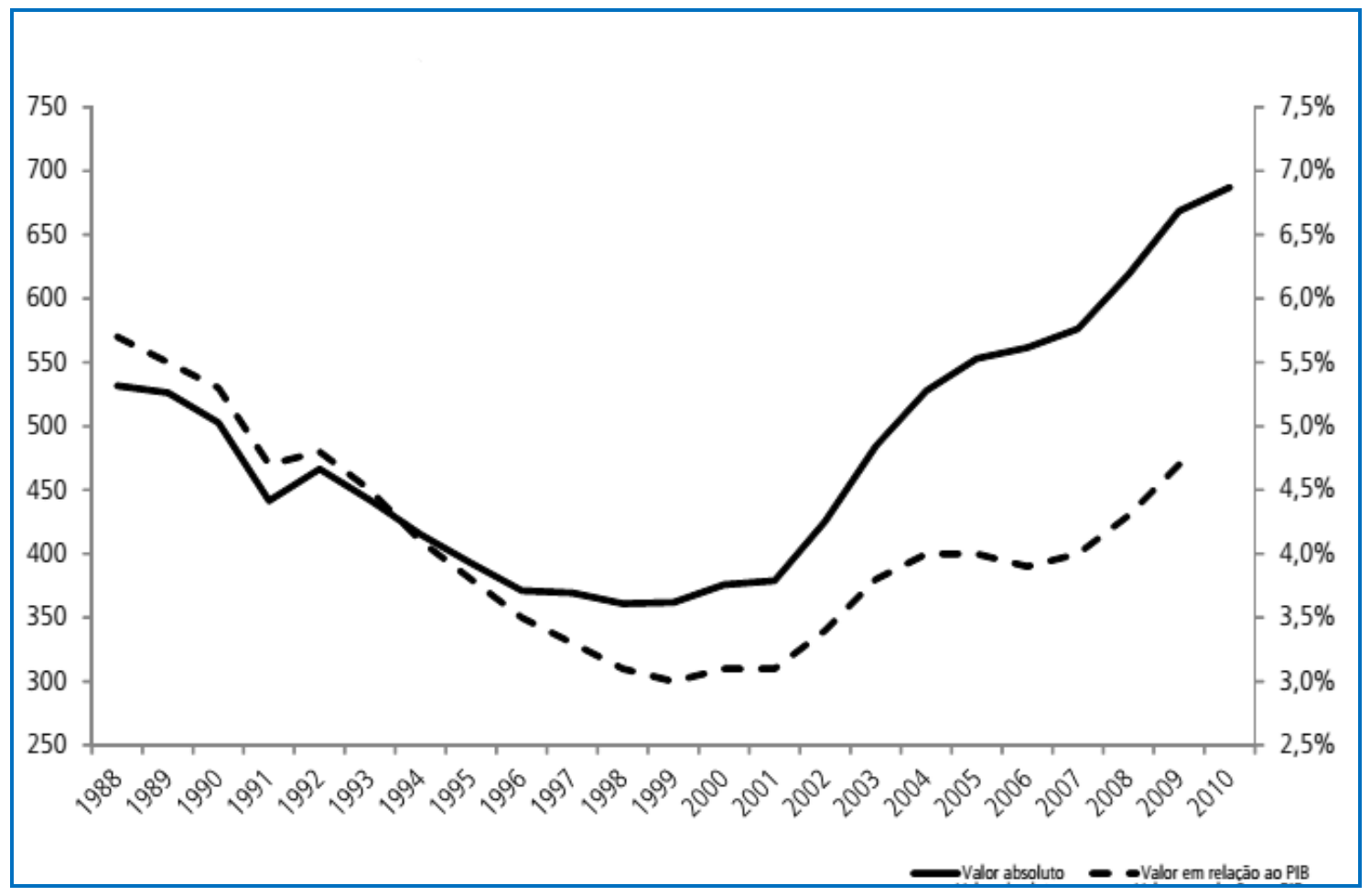

Fonte: Silva Filho e Fracalossi de Moraes (2012).

O estudo do Instituto de Pesquisa Econômica Aplicada (IPEA), fonte do Gráfico 1, flagra o aparente paradoxo entre o fim da Guerra Fria e a continuidade da gendarmaria internacional, comprovando que a afirmação de Braverman quanto ao caráter econômico das guerras, já apontado por outros teóricos, tem toda procedência. A pesquisa, apoiada em outras investigações sobre o assunto, apresenta um quadro de grandes investimentos militares, principalmente entre os países que constituem o Conselho de Segurança da Organização das Nações Unidas (ONU), Estados Unidos, China, Rússia, França e Reino Unido, seguidos pelo Japão, exatamente nessa ordem. Ali, os autores do documento dizem que "entre 2000 e 2009 os gastos militares subiram de US\$ 1,05 trilhão para US\$ 1,56 trilhão, crescimento de 48,9\%" (SILVA FILHO e FRACALOSSI DE MORAES, 2012, p. 27).

Alguns países que estão em um patamar abaixo desse grupo central, como a Arábia Saudita, a Índia, o Brasil e a Coreia do Sul, também operam com elevados gastos militares, tendo em conta suas condições econômicas e sociais. Considerando os dados de 2011, o Brasil gastou US\$ 34 bilhões com seu aparato de 
defesa nacional. A Índia, com investimentos de US\$ 44,3 bilhões, chegou a suplantar países europeus de tradição militar, como é o caso da Alemanha, cujas despesas com a defesa, US\$ 43,5 bilhões, ficaram quase 1 bilhão abaixo dos indianos. Superou igualmente a Itália, cujos gastos militares, no ano referido, foram de US\$ 31,9 bilhões (SILVA FILHO e FRACALOSSI DE MORAES, 2012, p. 12).

Certamente, esses gastos, essencialmente realizados pelo Estado, têm importância crescente para o escoamento do excedente econômico e da acumulação de capital. Eles não só têm um significado no presente, como vão se integrar à estrutura capitalista (produção, emprego, consumo, lucro, renda, investimento etc.) desses países. Frequentemente, as soluções para os impasses do capitalismo acabam por se transformar em novos problemas. Esse é um caso bem ilustrativo, porque é difícil os países que integraram expressivamente os gastos militares à sua estrutura econômica desfazerem-se deles ou reduzi-los de modo significativo. Menos ainda terão um engajamento sincero e consequente nos esforços pela paz.

Um terceiro plano de intervenção do Estado diz respeito à miséria e à insegurança social. Nas palavras de Braverman, esses dois pontos "tornaram-se aspectos mais ou menos permanentes da vida social e aumentaram para além da capacidade das filantropias privadas de controlá-las" (BRAVERMAN, 1977, p. 244). O autor identifica "medidas para o bem-estar a serem adotadas" sem as quais "os movimentos revolucionários ganhariam terreno" (BRAVERMAN, 1977, p. 244). Nesse caso, está referindo-se a programas estatais de assistência social que venham ao encontro das necessidades mais básicas das populações, cuja renda pessoal não é suficiente para atendê-las. Com isso, supõe o autor, o Estado amenizaria as tensões produzidas pelas desigualdades, além de obter os óbvios efeitos econômicos no plano do consumo agregado. "Essas e outras fontes de descontentamento são concentradas nas grandes cidades e, ao persistirem sem melhoria, ameaçam a própria existência da estrutura social", diz Braverman (1977, p. 244). O papel do Estado, nessa dimensão, foi tornando-se cada vez maior, a partir da Lei dos Pobres, mas, principalmente, quando, de fato, a agitação social e a organização dos trabalhadores cresceram, no final do século XIX e no aprofundamento do monopolismo. O Estado de Bem-Estar Social, implementado no segundo pós-guerra, foi a assunção definitiva da política assistencial. Ele se difundiu, como dissemos, por todos os países, independentemente do nível de desenvolvimento, ainda que, como Titmus (1963) chama a atenção, em graus diferentes de amplitude e cobertura social. Recentemente, os Estados Unidos deram um passo adiante no desenvolvimento dessa dimensão estatal, ampliando seu programa de saúde. Segundo a Organização Mundial da Saúde (OMS), em seu Relatório de 2013, os norte-americanos estão destinando à saúde 17,6\% de seu PIB. Contudo, a presença estatal nesse campo de preocupações sociais é significativa em diversos outros países, centrais e periféricos. A Holanda investe o equivalente a 12,1\% de seu PIB, a França, $11,7 \%$, a Alemanha, 11,5\%, a Suíça, 10,9\%. Na América do Sul, o Paraguai, com 9,6\%, o Brasil, com 9\%, a Argentina, com 8,3\%, o Chile, com 7,4\% e a Colômbia, com 6,5\% sobre o PIB estão, excetuando o Paraguai, com investimentos abaixo da média mundial, $9,2 \%$. Ainda assim, são recursos públicos expressivos que comparecem ao mercado consumidor (OMS, 2013).

De modo geral, portanto, o Estado opera na área da saúde com expressivas somas de gastos governamentais, tendo, assim, um papel importante nessa dimensão das políticas sociais à qual se refere Braverman. Além dos gastos com saúde, devem-se somar outras despesas estatais no plano social, destinadas a aliviar o sofrimento e as dificuldades dessas populações e reduzir a tensão política advinda do status de privação e desigualdade. No campo social, são realizados, em conformidade com o maior ou menor engajamento dos governos, gastos públicos com transporte, habitação, alimentação, além de outros, como no caso brasileiro, com suas políticas compensatórias, destinadas a segmentos miseráveis da população ou vítimas - credoras de dívidas históricas - como negros e índios.

Finalmente, Braverman (1977, p. 244) se refere aos demais serviços prestados pelo Estado, alguns deles clássicos, mas que se tornaram volumosos e expansivos com o que ele denomina "a rápida urbanização da sociedade e o aceleramento do ritmo de vida econômica e social". Ele destaca o aparelho educacional, cujo papel seria, além de proporcionar o aprender, adquirir a sabedoria para lidar com a rotina e, ao mesmo tempo, com a velocidade da maquinaria de um meio que já não é mais o meio natural de seus antepassados. Diz o autor: "com o desaparecimento da fazenda e da aldeia como as principais arenas de educação infantil, a responsabilidade pelo cuidado e socialização das crianças tornou-se cada vez mais institucionalizada" 
(BRAVERMAN, 1977, p. 244). Braverman não está incluindo, nessas observações sobre a educação, o provimento das necessidades ocupacionais, assunto que veio a ser tratado em outra sessão do livro. Entretanto, é evidente que, ao se enumerar as atividades desempenhadas pelo Estado, na composição de seu papel, não podemos deixar de incluir os muitos programas de capacitação de pessoal, treinamento e reciclagem realizados com recursos públicos, direta ou indiretamente. Afora os cursos de bacharelado, há os cursos tecnológicos que integram as universidades, dentre elas muitas mantidas por fundos públicos. Acrescem-se os cursos de pós-graduação e similares, muitos deles igualmente gastos públicos. Além da educação, a saúde, como vimos, expande-se a cada ano, como também se expandem outros serviços, por exemplo, os serviços de segurança pública e penitenciária, impulsionados pela "amargurada e antagonística vida social das cidades" (BRAVERMAN, 1977, p. 245).

Os gastos governamentais com segurança pública são um bom exemplo dessa referência. Falando do Brasil, que nos é mais próximo, as despesas públicas com a segurança tiveram crescimento de 15,83\% em 2012, em relação a 2011. Segundo o Fórum Brasileiro de Segurança Pública (FBSP), naquele ano foram gastos R\$ 61,1 bilhões, considerando todos os estados da Federação. O estado de São Paulo, o de maior dispêndio na função segurança pública, chegou a $\mathrm{R} \$ 14,37$ bilhões, pouco menos de 1/10 do orçamento estadual. Ali, o incremento de gastos públicos com segurança foi de 17,2\%, acima da média nacional. Minas Gerais e Rio de Janeiro tiveram despesas menores, $\mathrm{R} \$ 7,5$ e $\mathrm{R} \$ 5,6$ bilhões respectivamente, valores que, entretanto, estiveram entre os mais elevados das funções orçamentárias desses Estados (FBSP, 2013).

Concluindo o capítulo, Braverman (1977, p. 245) observa que "o aumento dos gastos governamentais, relativamente lento nos primeiros cinquenta anos do capitalismo monopolista, torna-se extremamente rápido daí por diante”. Ele reproduz a tabela com que Baran e Sweezzy (1982) demonstram a evolução dos gastos públicos nos Estados Unidos, ao longo de parte do século XX. Ali se vê que esses gastos governamentais, que representavam 1,7\% do PNB, em 1903, evoluem para 28,8\% do produto nacional em 1961.

Não foi um fenômeno dos Estados Unidos, mas um processo mundial que acompanhou o desenvolvimento do capitalismo no decorrer de todo o século passado. Indo além do marco usado por Baran e Sweezzy (1982), comparando-o com os dados que Tanzi (2000) coletou até 1996, podemos dizer que aqueles autores ainda não haviam observado o espetáculo de gastos governamentais que estaria por vir. A partir da Grande Depressão, nos últimos anos da década de 1930, os orçamentos públicos subiram para a média de 23,8\% dos respectivos PIBs. A seguir, após a Segunda Guerra Mundial, aproximaram-se da casa dos $30 \%$ (28,0\% em média) e, em 1996, chegaram à marca de 45,6\% dos seus produtos brutos. A média das despesas públicas dos principais países do mundo, calculada sobre o PIB, tomando os extremos da reta, evoluiu de $13,1 \%$ antes da Primeira Guerra Mundial para 45,6\%, em 1996, registrando-se casos como Alemanha (49,1\%), Noruega $(49,2 \%)$, Holanda (49,3\%), Áustria (51,6\%), Itália (52,7\%), Bélgica (52,9\%), França (55\%) e Suécia (64,2\%) que liderou o ranking de despesas públicas em percentagem do PIB (TANZI e SCHUKNECHT, 2000, p. 4$5)$.

Países como a Noruega e a Austrália quase que duplicaram suas despesas públicas daquela data de 1961 para 1996. Outros, como o Japão, a Espanha, a Suíça e a Suécia mais que dobraram seus gastos e todos, sem exceção, aumentaram estes dispêndios no mesmo período.

Pode-se dizer que, em relação ao assunto, o mesmo que ocorreu com os gastos militares veio a ocorrer com as despesas públicas em geral. Com o fim da Guerra Fria, como vimos, não pararam, mas, ao contrário, cresceram as despesas militares dos países centrais e de alguns periféricos. Do mesmo modo, as reformas de Estado, todas incentivadas pelo discurso de menos impostos e menos gastos públicos, foram acompanhadas pelo aparentemente paradoxal crescimento das despesas governamentais em alguns Estados.

Países que foram simbólicos em relação às reformas neoliberais, como o Reino Unido e os Estados Unidos, não sentiram efeitos consistentes da onda de Estado mínimo que eles próprios impulsionaram pelo mundo. Ao contrário, em meado dos anos 1990, registravam taxas de despesas governamentais maiores que aquelas com que iniciaram a década. 
A despeito das pontuais reduções, todos continuaram com níveis elevados de despesas públicas, que estão longe daqueles níveis do início do século XX, como se pode ver na Tabela 1.

Tabela 1

\section{Gastos públicos em relação ao percentual do PIB de países selecionados da OCDE (1975-2000)}

\begin{tabular}{|c|c|c|c|c|c|c|}
\hline Países & $\mathbf{1 9 7 5}$ & $\mathbf{1 9 8 0}$ & $\mathbf{1 9 8 5}$ & $\mathbf{1 9 9 0}$ & $\mathbf{1 9 9 5}$ & $\mathbf{2 0 0 0}$ \\
\hline Estados Unidos & 33,5 & 31,4 & 32,9 & 37,1 & 37,0 & 34,2 \\
\hline Japão & 26,8 & 32,0 & 31,6 & 31,8 & 36,5 & 39,2 \\
\hline Alemanha & 48,4 & 47,9 & 47,0 & 43,6 & 48,3 & 45,1 \\
\hline França & 43,4 & 46,1 & 52,2 & 49,4 & 54,4 & 51,6 \\
\hline Itália & 41,6 & 42,1 & 51,2 & 52,9 & 52,5 & 46,1 \\
\hline Reino Unido & 44,4 & 43,0 & 44,0 & 42,4 & 44,9 & 37,5 \\
\hline Canadá & 38,5 & 38,8 & 45,3 & 48,8 & 48,5 & 41,1 \\
\hline Dinamarca & 48,2 & 56,2 & 59,3 & 55,9 & 59,5 & 53,9 \\
\hline Países Baixos & 51,2 & 55,8 & 57,1 & 52,9 & 50,0 & 44,0 \\
\hline
\end{tabular}

Fonte: Giacomoni (2010, p. 18).

Dados mais recentes da Organização para a Cooperação e Desenvolvimento Econômico (OCDE), cobrindo o período de 1990 a 2008, revelam um comportamento menos homogêneo. Alguns países, em 2008, elevaram seus gastos governamentais, como é o caso, mais uma vez, do Reino Unido e dos Estados Unidos, chegando a 47,4\% e 38,7\% dos respectivos PIB e PNB. Outros, como a Suécia e a Alemanha tiveram fortes reduções, caindo de $64,2 \%$ para $53,1 \%$ e de $49,1 \%$ para $43,7 \%$, respectivamente, no período de 1996 a 2008 (OCDE, 2009).

Portanto, com algumas quedas e outras elevações, os percentuais de gastos governamentais sobre a produção dos Estados nacionais cresceram consideravelmente no século passado e continuaram a crescer ou, no mínimo, mantiveram-se em patamares elevados no século XXI. No caso dos Estados Unidos, tomados por Braverman, Baran e Sweezzy como exemplo, podemos ver que seus gastos públicos são, hoje, bem mais elevados que os 28,8\% registrados em 1961 pelos autores. Estão acima em quase 10 pontos percentuais.

Em grande parte, adverte Braverman, esses gastos são canalizados "através da estrutura existente do mercado" (BRAVERMAN, 1977, p. 246). Isso significa dizer que os gastos com as unidades de saúde, com os centros educacionais, com transporte, estradas, são realizados por meio de contratos firmados com empresas privadas que prestam serviços e executam obras para que as políticas públicas e os programas de governo se tornem reais. De modo geral, por exemplo, um hospital do Estado demanda produtos de laboratórios privados, assim como se instala com macas, camas e outros utensílios adquiridos no mercado. Assim, também, os gastos realizados por aparelhos públicos, como aqueles que respondem por atividades exclusivas do Estado, ou assim consideradas, fazem-se com consumo de bens produzidos e comercializados pela estrutura do mercado. Todo o aparato de segurança pública recorre ao mercado para seu abastecimento e são poucos os países que mantêm unidades fabris para prover as necessidades de fardamento, armas e munições de suas polícias, para não falar dos veículos usados. A mesma lógica se pode desenvolver para o caso dos aparatos militares, as forças de segurança externa, cujas cifras de despesas já conhecemos. Elas também vão ao mercado para seu provimento, tanto de armamento leve como pesado. Uma indústria poderosa, em todos os sentidos, está construída e operando para atender a essas demandas.

Constitui-se, assim, com o Estado um sistema que compartilha com as famílias e as empresas o volume de demanda agregada que viabiliza o sistema. Produção e comercialização encontram, portanto, no Estado um importante aliado, no plano eminentemente econômico, como agente econômico, tout court. 


\section{Contradições, Crises e Expansão do Estado}

A presença do Estado, até esses quatro pontos destacados por Braverman, corresponde à evolução do capitalismo, ao longo do século XIX e 2/3 do século XX.

Poderiam ser citados outros papéis do Estado? Braverman procurou manter seu estudo fora de considerações de natureza puramente política ou filosófica, como, por exemplo, o papel ideológico do Estado, que poucos anos depois seria sistematizado por Althusser. Contudo, ainda assim, cabe a pergunta: que outros papéis estaria o Estado exercendo, no âmbito da economia política, em favor do desenvolvimento capitalista ao tempo em que Braverman escrevia sua obra?

Ousaríamos dizer que alguns outros papéis já poderiam ser identificados - todos da mesma natureza daqueles apontados por Braverman, em suas palavras - fazer-se "o emprego do poder do Estado para estimular o desenvolvimento do capitalismo" (BRAVERMAN, 1977, p. 242).

O Estado fez, principalmente ao longo do século XX, o provimento de necessidades estratégicas para o funcionamento das empresas, para as quais seriam necessários grandes investimentos que não pareciam atrativos aos empreendedores privados. Foram os fundos públicos, que, em grande parte do mundo, responsabilizaram-se por construir usinas provedoras de energia, de diferentes fontes; satélites e redes de comunicação, transportes de carga, por via férrea principalmente; estradas, portos e aeroportos. Além disso, quase toda a indústria pesada de metais e produtos químicos também foi suportada pelo Estado. É possível dizer que o Estado ofereceu a infraestrutura e os insumos básicos ao desenvolvimento do capitalismo moderno.

Nesse rol, pode-se incluir a produção de certos bens e serviços que são avaliados como necessários, a qual, entretanto, não é atrativa ao investimento privado. Ou serviços que são mais bem desempenhados pelo Estado, graças às facilidades do poder ou em face do caráter geral do benefício. No Japão, por exemplo, foi o Estado que impulsionou a industrialização e abriu os mercados internacionais às empresas privadas, seja os prospectando, seja por meio de linhas de financiamento à exportação e outras facilidades (JOHNSON, 1982). Essa é uma prática observada em outros países, inclusive no Brasil, no passado e na atualidade. Entretanto, nesse plano da produção, também se pode falar em certos bens imprescindíveis a algumas indústrias. Esse foi o caso dos aços planos e da Companhia Siderúrgica Nacional (CSN), para a indústria automobilística no Brasil, e é o caso dos semicondutores nos Estados Unidos, para o que o governo criou uma empresa pública, a Semiconductor Manufacturing Technology, de modo a garantir condições à produção e ao fornecimento do componente (MONTES, 2013, p. 51).

Esse apoio do Estado, em algumas situações, foi além do fornecimento ou da criação de condições para a produção das empresas privadas. Tomando o Brasil como exemplo, as políticas de incentivo ao investimento privado, muitas vezes, operaram com o provimento de insumos a preços subsidiados, como se deu no caso da eletricidade, dos serviços de transporte ferroviário de cargas e das telecomunicações, que, por muitos anos, foram garantidos às empresas por valores inferiores aos custos de geração e funcionamento (BIONDI, 2003). O Estado pretendia, com isso, viabilizar baixos custos da produção final dos bens. O mesmo teria ocorrido com a siderurgia, cujos preços cobrados da indústria automobilística, por exemplo, chegaram a ser subsidiados em 75\% (GRACIOLLI, 2007, p. 221). Segundo Simonsen (1989, p. 16), ex-ministro da Fazenda no Brasil, "entre 1980 e 1986 o governo administrou os preços dos bens e serviços supridos pelas empresas estatais, reajustando-os bem abaixo da taxa de inflação". Utilizando dados oficiais, segundo seus cálculos "a defasagem acumulada foi de 15,6\% para a energia elétrica, 39,68\% para os aços planos, 38,9\% para o transporte ferroviários de cargas, 64,7\% para as telecomunicações, 52,4\% para os derivados de petróleo, 20,9\% para os serviços portuários, 26,6\% para o minério de ferro" (SIMONSEN, 1989, p. 16).

Também podemos dizer que as pesquisas, experimentos e testes que levaram e levam a avanços tecnológicos tiveram no Estado seu agente mais generoso. É sabido que os percentuais de investimento privado nesse campo têm sido pequenos, inclusive nos Estados Unidos, onde Drucker (2001) se queixava que 80\% das pesquisas inovadoras eram públicas. As pesquisas científicas são, frequentemente, consumidoras de tempo e 
de recursos, além de operarem com variados graus de incerteza - aspectos que não tornam atraentes esses investimentos. Uma variante desse papel é o trabalho de inovação e de difusão de novas técnicas, métodos e produtos, acompanhado por assistência técnica, que tem sido muito importante, em especial no agronegócio. O Estado, nesse caso, não só beneficia os pequenos produtores, mas produtores de todas as escalas, do que é exemplo, no Brasil, o desempenho da Empresa Brasileira de Pesquisa Agropecuária (Embrapa). A relação entre o Estado e as empresas, no plano da inovação, no Brasil e em outros países, continua fortemente marcada pela presença do Estado, diretamente ou via financiamentos às próprias empresas, parcerias e encomendas tecnológicas (BRASIL, 2006).

Nesse campo de interesse científico e tecnológico pode ser colocada a formação de certas profissões, especialmente na área da saúde e das chamadas ciências duras. Geralmente, é o Estado que implementa e executa projetos nessa área, seja porque se exigem imobilizações elevadas, em instalações físicas e equipamentos, seja porque o aproveitamento desses profissionais se dá de modo muito difuso e lento. Não é à toa que as universidades públicas são tão diversificadas como fonte da oferta de força de trabalho qualificada e, nessas formações mais dispendiosas, ciências da saúde e ciências duras, são quase exclusivas.

No espaço do desenvolvimento regional, o Estado tem sido fundamental para a criação de clusters, de distritos industriais e diversos outros arranjos produtivos locais. A disponibilização de infraestrutura, de incentivos fiscais e creditícios, de assistência técnica e até de relações públicas e políticas são, nessas iniciativas, papéis que o Estado desenvolve aparentemente sem substituto.

Alguns investimentos necessários à sociedade, mas igualmente úteis ao mercado, também não são atraentes a quem espera lucros o mais cedo possível, característica comum, ainda que não absoluta, da empresa privada. Tanto por força do volume de recursos que exige como pelo fato de seu retorno ocorrer de modo muito lento, tornando-se, em algumas áreas das cidades, até duvidoso, esses empreendimentos tocam ao Estado. É o caso dos investimentos em água e saneamento, por exemplo. Ou no transporte público de massa - trens e metrôs. Ou no fornecimento de gás e, em certas regiões mais distantes, na distribuição de eletricidade e até de combustíveis. Ainda que em alguns países, como o Brasil, algumas dessas atividades estejam hoje delegadas à gestão privada, todo o investimento em instalações produtivas e na rede de distribuição foi realizado pelo Estado. Não raramente é o Estado chamado a subsidiar novos investimentos ou, pelo menos, provê-los de recursos a taxas de juros quase negativas, por meio de seus bancos de fomento.

A propósito, falando em cidades, é o Estado que empreende grandes iniciativas de urbanização, representando investimentos expressivos, que se revertem em contratos com grandes grupos privados. Para Harvey (2009), na verdade, os investimentos em urbanização são, em muitos casos, uma fórmula de ativar o sistema e, em particular, consumir excedentes de capital. O autor identifica esse fenômeno nas grandes obras de Napoleão III, na Paris dos anos 1850, passando pela modernização de Nova York, em meados do século passado, até as grandes reformas urbanas chinesas. São avenidas abertas, pontes, galerias fluviais, aterros e, às vezes, bairros inteiros reconstruídos, como no caso de Les Halles, em Paris (HARVEY, 2009). Recentemente, o Rio de Janeiro foi objeto de intervenção mais modesta, porém, certamente, gratificante para as grandes empreiteiras de obra. Um elevado/viaduto, extremamente útil à mobilidade dos automóveis, foi destruído para dar lugar a um espaço novo, reurbanizado, no centro da cidade, à beira da Baía da Guanabara. Independentemente das polêmicas sobre o acerto da decisão, o fato é que não só geraram ganhos para as empresas da construção civil pesada como estão projetados para o novo espaço grandes e diversificados negócios.

O Estado também cumpre o papel de coordenação, regulação e estabilização, extremamente importante ao desenvolvimento do capitalismo. Sua intervenção por meio do monitoramento do crédito ou da administração fiscal ou, ainda, pelo controle do câmbio pode ser crucial em certos momentos nos quais a racionalidade do mercado precisa ir além do indivíduo e assumir caráter público. É o papel regulador, cujo reconhecimento se faz por parte até dos mais fundamentalistas neoliberais. Nos momentos de crise ou contração econômica, esse papel tem sido mais protagonista. Os agentes privados tendem a se retrair, observando o comportamento geral. Por exemplo, os bancos privados restringem o crédito, porque a confiabilidade cai em tempos de crise. Frequentemente, são os bancos públicos que fazem a movimentação 
anticíclica, provendo financiamentos que asseguram a continuidade do funcionamento do sistema. Nessa linha de considerações, pode-se incluir o custo do dinheiro, que tende a subir nos momentos de incerteza, mas tende a cair com a presença do crédito público. $\mathrm{O}$ mesmo pode ocorrer no mercado de moedas, que se torna agitado e perigoso nesses momentos difíceis, cumprindo o Estado um papel importante na coordenação dos agentes econômicos ou operando diretamente com compras e vendas de divisas.

Ainda que pareça uma heresia aos olhos dos gerencialistas, o Estado também pode ser um agente importante na elevação da eficiência de empresas privadas. É quando, em ambiente monopolista ou oligopolista, o setor público se introduz, oferecendo o produto a preços mais baixos. Isso rompe com o conforto em que os monopolistas ou oligopolistas se encontram. No Brasil, em tempos de elevada inflação, a Companhia Brasileira de Alimentos (Cobal) entrou no espaço dos supermercados, empurrando para baixo os preços dos alimentos, item fundamental na formação dos preços.

São dimensões que o Estado foi assumindo, à medida que a economia foi se tornando mais contraditória e complexa. Os empreendimentos foram exigindo mais investimentos e, em contrapartida, o erário foi se enriquecendo com fundos públicos das mais diversas origens. Os dados da Tabela 1 revelam tesouros nacionais riquíssimos, frequentemente próximos da metade dos PIBs nacionais.

Efetivamente, utilizando a terminologia de Gramsci, o Estado, no decorrer desse tempo, foi assumindo papéis cumulativos: do Estado carabineri para o Estado da revolução passiva, incorporando demandas sociais dos trabalhadores, seguindo-se o Estado intervencionista. Vale a pena dar maior atenção a esse processo, como passo preliminar para o entendimento da transformação do Estado em sua relação com o desenvolvimento capitalista.

\section{Evolução do Estado Moderno}

O Estado carabineri vai se explicitando quando se esgotam as esperanças do proletariado com o caráter progressista da burguesia. Uma incipiente, mas crescente, autonomia vai sendo adquirida pelos trabalhadores e suas organizações à medida que vão descobrindo que o capitalismo tem limites para sua revolução. A autonomia seguida da organização independente vão se constituindo em ameaça à nova classe dominante, a burguesia. Essa ameaça será reprimida, em todos os planos. É o Estado que, agora diretamente controlado, vai cumprir esse papel repressor, por meio das polícias, no plano interno dos países, e dos exércitos e armadas em geral, no plano externo, internacional. Greves, agitações sociais, ações diretas dos trabalhadores são reprimidas pela força policial-militar do Estado. Nos países em que grupos políticos anticapitalistas são bem-sucedidos em processos eleitorais e começam a realizar reformas, ou onde agitações sociais contrahegemônicas crescem a ponto de se transformar em rebeliões, ocorrem ocupações com o apoio das "forças aliadas", como nos casos que marcaram as intervenções militares, desde o século XIX.

No entanto, esse modo de combater as aspirações dos trabalhadores - reprimindo-os - cedo vai se revelar, em certas situações, inadequado e, de modo geral, insuficiente. $\mathrm{O}$ assunto, como se diria no Brasil, deixa de ser exclusivamente de polícia e passa a ser um assunto de política. Principalmente porque os próprios trabalhadores já haviam promovido a passagem de seus problemas do mundo restrito e privado das empresas para o mundo da disputa pelo poder e da opinião pública. Suas denúncias de baixos salários, relações de trabalho cruéis, além de outras injustiças praticadas pelo patronato com o apoio do Estado, começaram a repercutir nas campanhas eleitorais da democracia liberal.

A partir da década final do século XIX, a democracia burguesa se revelou um terreno onde as organizações operárias podiam construir algumas expectativas. O próprio Engels, na "Introdução" à primeira edição de Lutas de Classes em França (MARX, 1982a), chega a admitir possibilidades revolucionárias pelo voto. Cresce a corrente revisionista e evolucionista no âmbito do marxismo, onde se destacam Bernstein e Hilferding. Essa ascensão das ideias e dos partidos populares e socialistas, gradualista e eleitoral, parecia inevitável. O sufrágio universal poderia ser, como escreveu Engels (MARX e ENGELS, 1982, p. 103), “um 
modo de luta totalmente novo do proletariado, modo de luta esse que rapidamente se desenvolveu", apesar de todos os entraves colocados, tais como votos censitários e qualificados, além das formas grosseiras de manipulação eleitoral praticadas, como observa Losurdo (2004), a propósito da democracia liberal.

A revolução passiva é o recurso de que lançam mão os governos europeus ameaçados para conter essa onda popular nas eleições. Eles vão promovendo concessões e incorporando reivindicações dos trabalhadores jornada de 8 horas, previdência social, seguro-desemprego, proibição do trabalho infantil etc. - realizando um gradual transformismo no capitalismo. Esse processo se torna tão poderoso como meio de desmobilização que Kurz chega a atribuir aos movimentos socialistas e comunistas a paradoxal propriedade de promover a sobrevivência e adaptação do capitalismo, à medida que identifica seus males e pressiona por mudanças, por meio dos sindicatos e dos partidos (KURZ, 1991) ${ }^{3}$. Também vale lembrar que esse processo de revolução sem jacobinismo, como diz Gramsci, vem reforçar o revisionismo evolucionista típico da tese bernsteiniana, que, por sua vez, incentiva o desarmamento revolucionário. O chamado Estado social de direito, que depois evoluirá até o Estado de Bem-Estar Social, é, portanto, o passo mais relevante dado pelo capitalismo na virada do século XIX para o século XX (ESPING-ANDERSEN, 1991).

A seguir, procede-se ao intervencionismo econômico, quando, em plena crise dos anos 1930, acompanhando ensinamentos de Myrdal, Kalecki e Keynes, com doses variadas e referências discretas a cada um deles, concede-se ao Estado um papel regulador absolutamente herético à luz do classicismo e do neoclassicismo.

Seja pelo capitalismo organizado de Hilferding, seja pela experiência social-democrata sueca e, principalmente, pela mais expressiva e ruidosa experiência norte-americana, o New Deal, tem-se no primeiro $1 / 3$ do século XX o marco inicial da intervenção econômica do Estado. Os governos passam a responder pela infraestrutura - estradas, ferrovias, armazenamento, portos, aeroportos etc. - e, também, por insumos básicos - energia, telefonia, telecomunicação etc. - quando não pela mineração e provimento de matérias-primas necessárias às empresas. Trata-se de um Estado que também estará preocupado em assegurar a demanda efetiva, como já vimos na sessão anterior. Para isso, ele também vai se responsabilizar direta e indiretamente pelo nível de emprego, em busca do que Keynes chamaria de pleno emprego. Em palavras mais claras e para maior precisão, uma taxa baixa de desemprego, além de salários que permitam integrar os trabalhadores ao mercado consumidor. Do ponto de vista da teoria econômica, significa uma entrada profunda no plano individual e das empresas, uma vez que o assunto - emprego e salário - é, em princípio, fruto de uma relação essencialmente de troca (dinheiro por força de trabalho), aliás, marca original da relação social de produção no capitalismo (MARX, 2011). O fato é que, mesmo nesse plano, tão autenticamente capitalista, o Estado passa a intervir como regulador, fixando até as correções salariais e outros aspectos das relações contratuais entre patrões e empregados.

Esse resgate da evolução do papel do Estado serve para demonstrar que sua história está intimamente ligada ao desenvolvimento do capitalismo e, ao mesmo tempo, ao aguçamento das contradições do sistema - dois aspectos que caminham juntos. Como já observamos na "Introdução" deste artigo, salvo no que Marx denomina acumulação primitiva, essencialmente realizada sob o poder feudal, o papel do Estado no desenvolvimento do capitalismo foi inicialmente residual. Podemos reafirmar que, em grande parte, o Estado contrariava o interesse burguês. As bandeiras que marcaram a burguesia francesa - laissez faire, laissez passé - são ilustrativas das limitações que o Estado impunha.

3 Em entrevista concedida, em 1999, a Dieter Heidmann, professor do Departamento de Geografia da Universidade de São Paulo (USP), que destacava seu então recente O livro negro do capitalismo: um epodo à economia de mercado, Kurz declara que "o 'marxismo do movimento operário' entendeu equivocadamente as formas elementares da socialização capitalista (trabalho abstrato, valor/forma-mercadoria, dinheiro, mercado, Estado, nação, democracia) como condições existenciais sociais positivas, quase ontológicas. Nessa base, aparentemente neutra, realizou sua parte da 'luta de classes'. Por isso, a 'luta de classes' era apenas uma forma de concorrência interna das categorias capitalistas e do seu invólucro férreo. Tratava-se de lutas por distribuição, melhorias e 'direitos', cujo êxito parcial e sempre passageiro atava, cada vez mais fortemente, os homens ao sistema dominante, ainda na sua própria forma-sujeito” (KURZ, 1999). 
Contudo, vemos com facilidade que, no decorrer dos anos, quando a luta de classes econômicas vai se adensando e se potencializando com a luta de classe política, o Estado vai sendo chamado a exercer papéis mais refinados que o do Estado gendarme ou carabineri. Do mesmo modo, quando a contradição fundamental do sistema - produção social $\times$ apropriação individual - vai gerando crises de superprodução/subconsumo, em ciclos cada vez mais curtos, é igualmente o Estado que entra em cena com o intervencionismo econômico capaz de regular a economia, como o mercado não conseguia fazer.

Em outras palavras, o papel do Estado vem crescendo significativamente. As novas crises conhecidas após o lançamento de Trabalho e capital monopolista trouxeram, igualmente, novas funções. Essas novas funções não negam o conceito marxista de Estado, enquanto comitê político dos assuntos comuns da classe dominante. Tampouco negam as dimensões apontadas por Braverman em seu capítulo sobre o papel do Estado.

No entanto, a contemporaneidade acrescentou outras situações e atividades que confirmam a relação entre desenvolvimento, crises, contradições do sistema e o papel do poder político. Essas situações e atividades imprimem um redesenho que torna mais clara a relação entre Estado, mercado e sociedade. Além disso, permite que sejam observados alguns aspectos, até então muito discretos ou opacos, dessa relação. Entre esses aspectos, dois especialmente interessantes: um que diz respeito ao caráter inovador da intervenção contemporânea; outro que depõe sobre a profundidade crescente dessas intervenções. Além disso, talvez já se possa falar em um processo expansivo e ilimitado, para o qual não há fronteira entre o público e o privado que tenha sobrevivido. Nesse sentido, é totalmente démodé falar de intervenção do Estado no mercado. Estado e mercado constituem uma totalidade dialética.

É sobre isso que desenvolveremos a sessão a seguir, inicialmente abordando as novas atividades do Estado no contexto que acabamos de identificar como contemporâneo e que se abre com a crise dos anos 1970 e 1980 .

\section{O Estado Servidor: Crise de 1970 e 1980, Cessões, Parcerias e Gerenciamento de Crise}

Os anos após a Segunda Guerra Mundial foram de intenso crescimento da economia capitalista. Em particular, os Estados Unidos cresceram exponencialmente. A vitória militar se converteu em vitória política e esta em hegemonia econômica. Em grande parte por meio da posição privilegiada a partir do Acordo de Bretton-Woods e do Plano Marshall, os norte-americanos controlaram os mercados europeus, seja no plano da produção e comercialização, seja no plano das operações financeiras (HOGAN, 1987; HARVEY, 1994; HOBSBAWN, 1995). O PIB norte-americano vai em crescendo ininterrupto, partindo de US\$ 91,1 bilhões em 1939 para US\$ 258 bilhões em 1949, US\$ 482,1 bilhões em 1959 e 518,7 em 1961 (BARAN e SWEEZZY, 1982, p. 119). Nos anos 1960, ainda que já se registre queda nas taxas de crescimento do PNB dos EUA, elas se mantêm no patamar bastante razoável de 4,4\% em média anual, o que em termos de produto não deixa de ser expressivo, dado o volume sobre o qual incidia.

No entanto, além dos Estados Unidos, cresce o Japão, a uma taxa média anual de 10,4\%. Em rigor, todos os países de capitalismo desenvolvido experimentaram, naquela década de 1960, crescimento a taxas médias elevadas, que a OCDE calcula em 5,1\% ao ano (OCDE, 1986).

Dois fatores são especialmente importantes para esses resultados: o fordismo, com seu modelo de produção em massa, cuja linha de montagem se tornou processo comum a todas as empresas, e o papel do Estado como agente promotor do desenvolvimento econômico, conforme vimos. A expressão modelo keynesianofordista refere-se exatamente a essa combinação muito bem-sucedida de microeconomia fordista com macroeconomia keynesiana, ainda que, em vários países, seja possível dizer que o Estado foi além de Keynes. 
O virtuoso modelo garantiu elevada produção, a custos relativamente baixos, dada a escala obtida, que encontra circulação garantida pelas famílias, pelas próprias empresas e pelas políticas públicas do Estado, cujos cofres se mantinham abastecidos com os tributos pagos. Era um círculo continuamente crescente, a partir, é claro, da demanda efetiva, igualmente ininterrupta.

É exatamente nesse ponto que reside, como já se comentou, a fragilidade do sistema, e, por conseguinte, do modelo. A questão da demanda efetiva é inclusive a origem de várias outras crises ou contrações econômicas cíclicas.

Do final dos anos 1960 para os anos subsequentes, as taxas de crescimento dos países capitalistas centrais, com repercussão sobre toda a economia capitalista, desceram a níveis muito baixos, caindo da referida média mundial de $5,1 \%$ para $2,2 \%$, com casos extremos como o Japão cuja taxa de crescimento despencou de $10 \%$ nos anos 1960 para 4\% nos anos 1970 e 1980. O mesmo se poderia dizer da França, que de 5,9\% caiu para $1,2 \%$ no mesmo período (HARVEY, 1994).

A partir de então, instala-se um processo crítico, cujo foco central é o Estado, apontado como responsável pela crise. Os textos de Hayeck e de todos os que constituíram a Societé de Mont Pelérin, precursores do neoliberalismo, voltam à cena. O economista austríaco ganhou o Premio Nobel de Economia em 1974, como um sinal de que seu precoce ataque ao capitalismo de Estado, realizado em 1944, poderia ser visto como tão premonitório do futuro quanto o irônico trocadilho de números, o 1984, de George Orwell.

Aqui no Brasil, Bresser-Pereira (1997, p. 9), no auge da reforma do aparelho do Estado, afirmou que "a Grande Depressão dos anos 30 decorreu do mal funcionamento do mercado, a Grande Crise dos anos 80, do colapso do Estado Social do século vinte". Em outras palavras, "a grande crise dos anos 30 originou-se no mal funcionamento do mercado [...]. Esta crise, porém, não tem mais como causa a insuficiência crônica de demanda de que falava Keynes. Esta é a causa da crise do mercado nos anos 20 e 30. [...] Sua causa fundamental será agora a crise do Estado" (BRESSER-PEREIRA, 1997, p. 10-12). Essa tese fundamental, comum ao discurso das reformas do Estado recentes, foi reafirmada seis anos depois, quando o mesmo Bresser-Pereira (2003, p. 23) escreve que "a causa básica da grande crise dos anos 1980 foi o Estado: uma crise fiscal do Estado, uma crise do tipo de intervenção estatal e uma crise da forma burocrática de administração do Estado".

Nessa análise, o Estado aparece na cena da crise como um ator autônomo, capaz de ser responsável pela crise do sistema. Entretanto, a identificação da crise como uma crise fiscal acende a luz o suficiente para que se perceba a impossibilidade desse protagonismo. A crise fiscal não era uma crise proporcionada apenas pelo excesso de despesas, mas, também e principalmente, por uma crise de liquidez, essencialmente criada pela escassez de receita. Nos Estados Unidos, os anos 1970 e 1980 são de considerável queda da contribuição tributária das corporações e sobre as vendas (LAGEMANN e BORDIN, 1995, p. 364). É dessa época o rompimento de Reagan com o acordo de Bretton Woods e também o pico das taxas de juros pagos pelo tesouro dos Estados Unidos aos que adquiriam seus bônus (MUNEVAR, 2012, p. 216). No Brasil, Gobetti e Amado (2011) demonstram como cai a renda disponível do setor público entre os anos 1970 e 1980 e como, também, caíram as despesas de consumo e salário. Sobre o mesmo assunto, Simonsen (1989, p. 4), em artigo intitulado "A conta-corrente do governo: 1970-1988", também vai afirmar que "o verdadeiro drama é que o governo perdeu receita tributária real". Ele também se refere a que "na hora errada, (o governo) aumentou despesas de custeio", o que atribui ao "estilo populista" instituído após a redemocratização (1986). Como Simonsen está estudando na delimitação de 1970 a 1988, ao se referir ao aumento das despesas a partir da democratização (1986), está tratando apenas de 2 dos 18 anos estudados. Vale dizer: sem considerar a própria Constituição, promulgada em 1988. A perda da receita tributária, no período estudado, certamente terá pesado mais que os 2 anos de aumento das despesas do governo Sarney.

Foi essa falta de liquidez dos governos, fenômeno mundial, que transformou a crise financeira do Estado em uma crise política. É a crise política, proveniente da inefetividade das políticas públicas do Estado, sem receita tributária suficiente para fazer frente às demandas sociais e outros interesses públicos, que vai criar o ambiente adequado às reformas do Estado e, principalmente, à reforma do aparelho do Estado. $\mathrm{O}$ ambiente 
adequado, inclusive, para que se difunda a crença de que foi o Estado, e é o Estado, o grande vilão da crise dos anos 1970 e 1980.

A crise, porém, não pode ter outra origem que não o mercado. Como já havia observado Marx, a história não se explica pelos heróis ou pelas ações do Estado, mas o verdadeiro teatro da história é a sociedade civil, cuja essência é a economia política (MARX, 1982b).

É na economia política, na vertente fordista do modelo keynesiano-fordista, que tem início a crise. É também por essa vertente que se explica o tipo de reforma de aparelho do Estado que se desencadeou com grande apoio da mídia e, por consequência, da sociedade. É no mercado que se encontra o ponto de partida e o ponto de chegada da crise dos anos 1970 e 1980, passando pelo Estado, evidentemente. Portanto, a crise tem origem no mercado.

A compreensão desse fenômeno é absolutamente necessária para que se entenda um dos novos papéis do Estado contemporâneo. Cabe, portanto, um pouco mais de explicação.

De modo detalhado, devemos dizer que a crise começa com o esgotamento da padronização, como adverte Toffler (1985), em relatório para a American Telephone and Telegraph Company (AT\&T). A produção fordista, padronizada e duradoura, vai se tornar saturada e passa a não encontrar consumidores. O mercado oferta produtos que já se encontram nos estoques domésticos. As famílias que dispõem de capacidade de compra, nos anos 1970, já têm a geladeira, o fogão, a máquina de lavar, o telefone, o aparelho de arcondicionado, o automóvel, o rádio, a vitrola, enfim, tudo aquilo que compõe uma casa cuja renda familiar permite o consumo dos bens da modernidade. Os produtos que lotavam as lojas, naqueles anos, não tinham qualquer diferencial que os tornassem atraentes e que justificassem sua aquisição para substituir os que se encontravam em casa. Por isso, as famílias pararam de comprar. Em resposta, as empresas pararam de produzir. O que significa dizer que também pararam de comprar a matéria-prima, os materiais secundários, os insumos para produção etc. etc. Principalmente, pararam de contratar. Instala-se o círculo descendente de menos consumo, menos produção, menos emprego de fatores, menos renda, menos consumo...

Esse foi o problema básico. Ele se reflete em menos tributos arrecadados e, portanto, menos recursos para o erário, o que evidentemente repercute sobre a prática das políticas públicas. Por um lado, o primeiro efeito é a retração do Estado, que também deixa de comprar, de contratar e muitas vezes até de pagar suas dívidas. Por outro lado, os cidadãos se queixam do mau atendimento dos serviços públicos, quando não da ausência desses serviços. Vale dizer que nesses tempos de crise, as demandas sociais tendem a aumentar, acentuando as dificuldades do Estado.

No plano do capital, instala-se uma situação que Arrighi vai chamar de superacumulação. Isto é, o não investimento dos capitais na economia real vai fazer com que os capitais acumulados se dirijam aos bancos, aplicados que são em operações financeiras ou no mercado bursátil (ARRIGHI, 1996). Um volume elevado de capitais acumulados circula pelo mundo em busca de taxas de remuneração atraentes e de mercados desregulados.

Portanto, a crise se desdobra em duas frentes: ambas, mais uma vez, de demanda efetiva. A primeira frente, a da demanda efetiva das famílias e das empresas. A diferença em relação à crise dos anos 1930 é que a causa da baixa demanda efetiva das famílias e das empresas não se localizará na falta de liquidez do mercado, portanto, não se encontra na falta de capacidade aquisitiva do consumidor. Nessa ocasião, 1970 e 1980, a causa da baixa demanda efetiva se encontra na falta de atratividade da oferta. A segunda frente, diferentemente, é de falta de liquidez, mas já então da falta de liquidez do Estado, enfraquecido com o pequeno fluxo de tributos, seja porque as vendas caíram, seja porque a produção caiu, seja ainda porque a sonegação aumentou, como costuma acontecer em tempo de vacas magras.

Essa situação de superacumulação terá duas vias de enfrentamento. No âmbito da padronização, tratava-se de inovar, no sentido mais preciso do que ensina Schumpeter (1982). Inovação de produtos, como sempre acompanhada de inovação tecnológica, como lembra Toffler (1985). Isso vai reanimar o mercado 
consumidor. Essa via de enfrentamento da superacumulação faz com que parte do capital superacumulado saia do mercado financeiro e retorne à economia real, produzindo novos bens ou bens com melhorias, que atrairão os consumidores. É o tempo da gestão da qualidade, que Juran (1990, p. 46) define, em Planejando para a qualidade, como "conduzir melhoramentos contínuos". A segunda frente é a cessão de serviços e de ativos do Estado.

Essa operação de cessão de serviços e ativos, genericamente chamada de privatização, tornou-se volumosa e facilitada pelo próprio Estado, que ofereceu suas empresas públicas e, a seguir, seus serviços, não raro a preços de aquisição relativamente baixos, em certos casos financiados pelo próprio Estado. Pelos dados do Banco Mundial, nas décadas de 1980 e 1990 foram privatizadas 6.830 empresas públicas em todo o mundo (CHOMSKI e DIETRICH, 1999).

São negócios muito interessantes, com lucros elevados e imediatos, onde os capitais superacumulados puderam ser aplicados, saindo, assim, da chamada ciranda financeira e voltando à economia real, aquela que de fato cria valor e retoma a virtuosidade dos ciclos produtivos.

A cessão de serviços e de ativos do Estado, constituídos com investimentos públicos, é uma iniciativa nova, cujo sentido foi reabilitar o sistema a uma nova periodicidade de acumulação, operando mercados de grandes proporções, como a telefonia, a energia, o fornecimento de água, o transporte, a saúde, a educação e outras atividades que a cada dia são incorporadas à lista de serviços delegáveis à gestão e ao arrendamento privados.

Podemos, por isso, dizer que a crise dos anos 1970 e 1980 trouxe à cena um Estado prospector de negócios, cuja função incorpora uma virada ético-política. Explicando melhor: o Estado, diante dos capitais superacumulados, exerce a função de oferecer os serviços que presta ao investimento privado, abrindo frentes de negócio aos investidores. Para isso, rompe com o éthos da sociedade moderna - para a qual há serviços públicos econômicos e sociais de exclusiva competência do Estado e que devem ser por ele oferecidos, para que possam servir, de fato, à sociedade. Nisso estão incluídos todos os serviços sociais e direitos conquistados, mas, também, riquezas minerais e vegetais, como o petróleo ou o cobre, por exemplo, que eram frequentemente classificadas como estratégicas. Essa virada ético-política consiste essencialmente em converter valor público em mercadoria.

Como observa Harvey (2009, p. 10), "a política do capitalismo é dirigida pela necessidade de encontrar terrenos lucrativos para a absorção de capital excedente".

Essa política foi assumida pelo Estado. Não se trata, agora, de assegurar a demanda efetiva capaz de manter o circuito da acumulação pela via conhecida D-M-D', quando o Estado, como observa Braverman, preenche a "lacuna" que se cria entre a capacidade de consumo do mercado (individual/empresarial) e o volume de bens produzidos. Trata-se agora de um novo circuito a ser garantido pelo Estado: M-D'-M'--D', quando o Estado disponibiliza a mercadoria em que os capitais acumulados podem investir para retomar o processo de acumulação. Agora há uma lacuna nova e preliminar que o Estado vai preencher: M. Para isso, não se distinguem valor público e valor privado - todo valor é potencialmente mercadoria (M). Há, ainda, uma acumulação anterior, os investimentos públicos que fundaram o negócio privatizado ou delegado. São, por exemplo, os investimentos em usinas hidrelétricas ou nos satélites de telecomunicação, ou nas pontes, ou nos altos-fornos da siderurgia. Esses investimentos foram realizados pelo Estado e transferidos ou cedidos em M, quando o negócio é passado para o capital privado.

Esse papel do Estado revelou-se decisivo para a saída da crise e para abertura de um novo ciclo de acumulação. São mercados importantes, populosos, de demanda cativa, como o fornecimento de eletricidade, os portos e aeroportos, produtos siderúrgicos, serviços de telefonia, minérios, transporte, bancos e outros do mesmo porte. A eles se têm acrescido as áreas de educação e saúde.

Dados do Departamento de Comércio dos Estados Unidos demonstram o crescimento dos lucros empresariais a partir desse momento. São duas séries de anos, com comportamentos diferentes. A primeira, 
reunindo os anos que vão de 1960 a meados dos anos 1980, quando se percebe um volume de lucro privado estável, em torno de US\$ 150 a US\$ 200 bilhões. A segunda série de anos, desde 1986 até a crise de 2007 e 2008, mostra o nível dos lucros das empresas privadas passando para US\$ 400 bilhões em 1986, daí para US\$ 800 bilhões, no início dos anos 1990, e alcançando, em 2006, a casa dos US\$1.600 trilhões, quando a seguir se instala a crise aberta no mercado imobiliário (LEIVA, 2012, p. 95).

Em plano mundial, os dados do Fundo Monetário Internacional (FMI) também são testemunha da importância das cessões de espaço e mercantilização das atividades do Estado. A produção (média anual) mundial de bens e serviços, que nos anos 1980, andava em torno de US\$ 21 trilhões, saltou para a média anual de US\$ 70 trilhões, em 2008, com um crescimento superior a 200\% no período (LEIVA, 2012, p. 92).

O mesmo FMI (2007a) vai dizer que a força de trabalho quadruplicou nos dois últimos decênios, indicando a massa geradora de valor que se formou ao longo dos últimos 20 anos.

Esse papel do Estado não significa a consideração de que um setor econômico ou um setor social ou cultural, ora sob a administração do Estado, seja avaliado como mais adequadamente conduzido se delegado ao setor privado. Tais iniciativas e delegações são antigas. Elas se verificavam de modo pontual, por via das referidas concessões, principalmente. Ou em regime de comodato. Ou, ainda, pelo recurso à autorização ou permissão, figuras antigas do direito administrativo.

O que se efetivou recentemente, após a crise de superacumulação dos anos 1970 e 1980, quando os capitais ficaram sem alternativa de investimento, senão o mercado financeiro, é algo diferente. A operação ocorrida foi uma volumosa transferência patrimonial e não patrimonial de atividades estatais rentáveis e, em especial, a transformação de atividades estratégicas e sociais em atividades lucrativas, constituindo lotes de negócios extraordinariamente elásticos e com fronteiras amplas a serem exploradas.

Para isso, o Estado se despiu de sua especificidade e distanciamento ou pelo menos do que se entendeu e propagou como isso. Por muitos anos, o Estado foi apresentado como algo distinto da sociedade e do mercado, a ponto de alimentar-se a ideia de autonomia do Estado, tese muito cara aos weberianos de todas as linhagens. Contudo, uma virada significativa se verifica a partir dessa generosa postura de cessão de espaço do público ao privado e de mercantilização crescente da vida social. Essa virada consiste exatamente na redução ou supressão da fronteira entre as duas esferas. Assim como se pode falar em quase mercado, para se referir a atividades públicas conduzidas como se mercadoria fossem, pode-se falar em quase Estado para algumas atividades conduzidas pelo setor privado, com os privilégios do Estado: transportes públicos, energia, telefonia, pontes e estradas, portos e aeroportos, presídios e escolas, hospitais e museus. Portanto, a crise dos anos 1970 e 1980 coloca o Estado como um agente importante na viabilização de um processo de acumulação que agora começa com ele próprio. É o Estado que se encarrega de ceder seu valor transmudado em mercadoria (M) para abrir o ciclo de produção e reprodução do sistema a que já nos referimos.

Tendo como pano de fundo esta nova condição das esferas pública e privada crescentemente indiferenciadas, a crise de 1970 e 1980 vai acrescentar outro novo papel ao Estado em sua relação com o capitalismo: a parceria público-privada em sentido lato. Em sentido estrito, a parceria público-privada se parece com uma delegação do Estado a mais, o que faz com que alguns suponham estar diante apenas de novo tipo de concessão (BANDEIRA DE MELLO, 2005). Entretanto, o que de fato passa a ocorrer é a potencialização do mercado com recursos públicos, em sociedades mercantis reunindo o público e o privado, o que dá às parcerias público-privado, em senso estrito, o caráter de uma metonímia. É a parte que representa o todo, reconhecendo-se um sentido capitalista pleno ao Estado e às atividades do Estado.

O Estado institui uma parceria sem fim com o setor privado, transformando aquilo que Caio Prado Jr. (1987) caracterizava como "capitalismo burocrático", adstrito a um pequeno grupo de empresários com negócios na área pública, em enorme campo de variados negócios atraentes, quase todos monopólios (SAPPINGTON e STIGLITZ, 1987). 
No Brasil, o jornal $O$ Globo anuncia curiosamente que é o banco público nacional de fomento, Banco Nacional de Desenvolvimento Econômico e Social (BNDES), que assina as primeiras parcerias públicoprivadas: BNDES assina primeiros contratos de parcerias público-privadas. Na matéria, compreende-se melhor as razões: "O investimento para elevar a coleta de esgoto de $15 \%$ para $90 \%$ será de aproximadamente R \$ 375,9 milhões, sendo R \$ 263,1 milhões financiados pelo BNDES” (O GLOBO, 2008). O mesmo papel protagonista, respondendo pela maior parte dos recursos, vai ter o BNDES no programa de expansão do saneamento e da mobilidade urbana na Grande Vitória, conforme divulgou o próprio governo, em maio de 2010 (SKYSCRAPERCITY, 2010). Repete-se o comportamento nas construções e reformas dos estádios de futebol do Rio de Janeiro, de Belo Horizonte, de Manaus, de Salvador e do Rio Grande do Norte. A Agência Brasil, ao anunciar a parceria público-privada para a área da saúde, em Salvador, com a inauguração do Hospital Geral do Subúrbio, traz a interessante declaração do chefe do Departamento de Estruturação de Projetos do BNDES, Alexandre Porciúncula: "Bom para o poder concedente, para a população que vai ser atendida e para o setor privado também. Tem que ser uma coisa muito equilibrada e com uma visão de longo prazo" (AGÊNCIA BRASIL, 2010). O jornal $O$ Globo, a propósito das parcerias público-privadas, no "Caderno Economia" de 8 de maio de 2011, abre a manchete De hidrelétricas a refinarias e estádios, tá tudo dominado. Na matéria se lê que "uma quantidade de investimentos no país vista somente na época do 'milagre econômico', na década de 70, (as empresas) deixaram de ser apenas construtoras e se transformaram em verdadeiros conglomerados de infraestrutura, atuando em áreas que vão do petróleo e energia elétrica a telecomunicações e agronegócio" (O GLOBO, 2011).

A expressão para designar esse novo arranjo é contratualização, definida por Pontier $(1998$, p. 7) como "a substituição das relações comandadas pela subordinação pelas relações fundadas na discussão e na troca". Ele explica que o termo "contratualização" provém do termo contrato, mas é muito mais abrangente do que este.

Em interessante artigo que debate as concessões no novo cenário do capitalismo, Grotti (2007) destaca a diferença daquilo em que consistiam as concessões anteriores e o que se dá no presente. Para isso, ela mobiliza autores de diversos países que se referem às suas experiências nacionais muito semelhantes. Em trecho suficientemente rico, lê-se que

[...] o movimento de contratualização diz respeito à "passagem da Administração autoritária à Administração soberana consensual". Refere-se ao "aparecimento de uma nova mentalidade", que está em expansão, onde o acordo aparece em substituição aos atos unilaterais de autoridade, trazendo a lume o que se tem chamado de Administração Pública consensual (GROTTI, 2007, p. 4-5).

Talvez em breve já não caiba se referir à "administração pública consensual", mas, simplesmente, à "administração consensual", tamanha a indistinção entre o público e o privado.

Citando Medauar, em seu artigo com título muito sugestivo do que estamos discutindo, $O$ direito administrativo em evolução, Grotti (2007, p. 4) explica que

[...] diversificaram-se os modos de prestação de serviços públicos, observando-se, nas últimas décadas, o surgimento de novos tipos de ajuste, decorrentes de consenso, acordo, cooperação, emergindo o termo parceria, "vinculado à contratualização, para abranger os diversos ajustes que expressam a colaboração entre entidades públicas ou entre entidades públicas e setor privado, ou, ainda, entre todas estas partes, envolvendo, assim, uma pluralidade de atores".

Lembremos que a autora e suas referências escrevem na primeira década do século XXI. Portanto, é das iniciativas já referidas para enfrentar a crise dos anos 1970 e 1980, e das suas consequências, principalmente, que estão falando. 
Nesse ambiente de integração entre capitais públicos e privados, entre administração pública e privada, perfeitamente compatível com a onda gerencialista, quando as fronteiras se dissipam, um terceiro novo papel do Estado se consolida: o de gestor dos negócios privados. É um papel que se enfatiza em tempo de crise, mas que se desdobra a partir desse ponto. Ou se apresenta em nome de evitar a crise. A política protecionista a setores, onde se incluem as renúncias fiscais, que se tem praticado no Brasil com a indústria automobilística, a linha branca e a construção civil, é a antessala desse novo papel. O gerenciamento é um passo a mais no envolvimento direto do Estado com as empresas, a partir da crise de 2008 e se estendendo até nossos dias. Suas bases são anteriores à crise, mas seu aprofundamento é posterior.

Certamente, o caso mais ilustrativo desse papel é o da General Motors nos Estados Unidos. Ali se verificou uma intervenção de salvamento, em que recursos públicos foram empenhados para evitar falência ou consequências semelhantes, mas foi adiante. No Brasil, anteriormente, o programa de salvamento de bancos, denominado Programa de Estímulo à Reestruturação e ao Fortalecimento do Sistema Financeiro Nacional (Proer), investiu somas elevadas no Banco Nacional, Banco Econômico, Bamerindus, Mercantil, Banorte, Pontual e Crefisul. Segundo o site do Banco Central do Brasil (BCB), registrava-se, em 1995, que 589 instituições financeiras foram submetidas a regime especial, que inclui intervenção, regime de liquidação extrajudicial e, finalmente, regime de administração especial temporária (BCB, 2013).

O caso da General Motors também envolveu vultosa verba pública, mas não só. O governo Obama promoveu a intervenção fiscal, mas, também, uma intervenção administrativa e gerencial, afastando a alta direção da empresa e conduzindo o processo de salvamento diretamente. No âmbito do mesmo caso, dá-se a intervenção sobre os planos da Chrysler, praticamente obrigada a aceitar sua fusão com a FIAT, encarregada, a partir de então, de gerenciar a empresa norte-americana em troca de $20 \%$ de suas ações. Foi o que se pode denominar, na linguagem do setor, um pacote de intervenções que não guardou nenhum limite entre o público e o privado (MONTEIRO, 2010).

Essa relação empresarial e gerencial entre público e privado vai se desdobrando em operações cada vez mais íntimas. Em 2011, o The New York Times noticiou que "o Departamento do Tesouro contratou Perella Weinberg Partners para assessorar o governo na oferta pública inicial iminente da Ally Financial" (NEW YORK TIMES, 2011). Poucos dias depois, o The Wall Street Journal (2011) lembrava que "o Tesouro em 2009 investiu US\$ 17,2 bilhões em Ally Financial como parte do Troubled Asset Relief Program, o programa do governo de US\$ 700 bilhões destinado a estabilizar os mercados financeiros".

Perella Weinberg, Ally Financial, ex-GMAC, financeira da General Motors (GM) à época, e a própria GM têm profundas ligações que vão além do fato da Perella Weinberg se instalar no mesmo prédio da GM, em New York. As empresas fizeram com o governo, detentor de $74 \%$ das ações da Ally, um arranjo circular, sob os auspícios do Estado. Isto é, o Estado faz o gerenciamento da crise, utilizando seus recursos humanos e financeiros, transferindo US\$17,2 bilhões em troca de ações de uma instituição ameaçada, para, em seguida, gerenciar igualmente a bonança, devolvendo ao setor privado as ações adquiridas por ocasião do salvamento.

O caso da British Petroleum, mais recente, também é ilustrativo desse comportamento. Monteiro (2010, p. 1027) traz a informação de que "diante do desastre ambiental no Golfo do México, a British Petroleum é levada a criar, muito rapidamente, um fundo de indenização de US\$ 20 bilhões, recursos que não serão alocados pela BP, mas pelo governo federal".

A leitura do Washington Post (2010), na reportagem intitulada BP agrees to \$20 billion fund for gulf oil spill claims, nos traz o sugestivo comentário de que "o confronto muito aguardado quarta-feira na Casa Branca entre o presidente Obama e os principais executivos da BP se transformou em reunião de negócios". 


\section{Conclusão}

O capítulo de Braverman sobre o Estado e seu papel no capitalismo monopolista constitui, como dissemos na "Introdução", um texto contido, mas rico em nuances. Ele aponta "quatro ângulos gerais", com suas especificidades, todos estreitamente ligados à relevante questão da demanda efetiva, e estimula o leitor a pensar no presente.

Seus ângulos gerais - consumo, internacionalização do capital, assistência social e serviços básicos - todos, ao exame que fazemos hoje, são dimensões vivas do papel do Estado. Nada se pode dizer como superado ou inexistente, antes, é o contrário que se vê. Aos números de Braverman, pudemos acrescer dados atuais, demonstrando que não só continuam válidas suas identificações, mas se tornaram mais expressivas, a despeito do tempo, passados quarenta anos do lançamento de sua obra.

Vimos, por exemplo, como cresceram os gastos militares após o que se pode considerar o encerramento do longo período de Guerra Fria. Àquela época, de 1945 ao final dos anos 1980, em paralelo às escaramuças diplomáticas, Estados Unidos e União Soviética se enfrentavam indiretamente em choques armados nos territórios disputados por suas riquezas, seus mercados e sua posição estratégica. Supunha-se que a queda do poder soviético tivesse encerrado as disputas internacionais violentas, que consumiram bilhões de dólares e milhares de vidas humanas. A associação que Braverman faz entre as guerras e o capital monopolista, entretanto, revelou-se inabalável. A concorrência econômica que, para ele, está na base dos conflitos armados, continuou. Acima das disputas ideológicas, os interesses do capital em fontes de matéria-prima e materiais secundários, consumidores para seus produtos e favores para seus investimentos permaneceram e as disputas armadas, às vezes revestidas de aparência religiosa, multiplicaram-se no mundo.

Vimos, também, que sua afirmação de que as despesas públicas tiveram importância e volume crescentes na segunda metade do século XX se reafirmou no último quartil do século, que, infelizmente, Braverman não viveu.

Ainda que se possa observar certa mudança nos números de alguns países - Suécia, por exemplo - a verdade é que todo o esforço pelo Estado mínimo, desenvolvido nos anos de reforma do Estado e do aparelho do Estado, não foi suficiente para promover significativa redução das despesas públicas das nações. Na verdade, há países, entre eles, ironicamente, os Estados Unidos e o Reino Unido, que continuaram elevando as taxas de despesas governamentais sobre seus produtos nacionais.

As condições que levaram ao aparecimento do Estado como agente responsável por alguns papéis econômicos não desapareceram. Além disso, os problemas que motivaram o protagonismo dos governos não encontraram na responsabilidade social das empresas - conceito muito comentado, mas pouco efetivo - um sucedâneo do Estado. São questões militares, questões sociais e questões econômicas de grande vulto, muitas vezes, com baixas possibilidades de retorno, que, evidentemente, não podem ser assumidas pelas empresas, por mais generosa que seja a disposição de seus acionistas.

É o Estado que deve responder pela agenda dos grandes números, em grande parte gerada, é bem verdade, pelas consequências predatórias de um sistema que afeta a vida de variadas formas, desde o emprego precarizado e doenças do trabalho até a degradação do meio ambiente.

Essa agenda de grandes números não está restrita aos problemas, mas, também, a soluções que se tornam necessárias e que envolvem elevados investimentos, tais como a construção de portos, aeroportos, ferrovias e rodovias.

Essa diversidade de situações, que necessita de respostas, algumas imediatas, outras de médio e longo prazo, não diminuiu. Na verdade, tem crescido. Por isso, a partir dos quatro ângulos apontados por Braverman, foi possível perceber outros tantos e avançar ao longo do tempo para encontrar um Estado efetivamente transformado em sua própria natureza ou na natureza que as definições e caracterizações mais frequentes atribuem ao Estado e seu papel. 
Dividimos esses outros ângulos ou dimensões, como preferimos dizer, em dois grupos: primeiro, aquelas dimensões às quais Braverman não se referiu, mas que, à sua época, já podiam ser percebidas. Em segundo lugar, identificamos um conjunto de novas dimensões emergentes após as duas últimas grandes crises do capital - a ocorrida entre os anos 1970 e 1980 e aquela que se abriu em 2008, com o estouro da bolha imobiliária.

No primeiro grupo, relembrando, estão:

- o provimento de demandas estratégicas e externas às empresas, como as instalações infraestruturais e os empreendimentos necessários à produção e fornecimento de insumos básicos e materiais;

- o apoio material, financeiro e diplomático à expansão internacional dos negócios privados do país;

- a garantia de preços subsidiados de matéria-prima, componentes e insumos necessários á produção, como parte da política de incentivos;

- o fomento da pesquisa e da inovação;

- a formação de profissionais especializados em áreas específicas da produção;

- a implementação e o apoio a clusters, distritos industriais e outros arranjos produtivos locais;

- a criação, a manutenção, a expansão e a modernização de serviços urbanos como transportes de massa, conservação das vias públicas, fornecimento de gás e energia, necessários à habitação e mobilidade dos trabalhadores urbanos e rurais;

- o lançamento, a implementação e a execução de grandes reformas urbanísticas, com repercussões sobre o consumo, o emprego, a valorização de áreas privadas e novos investimentos;

- a regulação, a coordenação dos agentes econômicos e as políticas de estabilização destinadas à manutenção das bases concorrenciais e ao enfrentamento das crises setoriais e gerais do sistema.

Contudo, é no segundo grupo em que se encontram as novas dimensões do Estado, aquelas que em nossa avaliação representam uma mudança em seu caráter.

Até então, ainda que se afirmando como uma criação a serviço da classe dominante, como diria o próprio Braverman, a ação do Estado guardava certa distância que permitia distinguir valor público e valor privado. Isso assegurava que a esfera pública poderia ser delimitada com exatidão. Igualmente se tornava uma expectativa razoável que determinadas atividades sempre seriam públicas, para que seus efeitos fossem equanimemente distribuídos. Nenhuma hipótese de que, por exemplo, os presídios poderiam ser administrados por entes privados ou que a guerra pudesse ser feita por agentes terceirizados, contratados pelo Estado de empresas privadas. Ou que a saúde pública viesse a ser provida por um grupo privado.

As crises que se sucederam a partir dos anos 1970 puseram o Estado em uma nova posição. Essa nova posição é aquela que nos sugere estar diante, nos tempos atuais, não de um Estado interventor, mas de um Estado servidor. Um Estado disponível e disposto a fazer o que se mostrar necessário à manutenção e reprodução das empresas e dos agentes econômicos. Não uma postura que em nome do sistema será capaz de impor ao sistema o sacrifício de alguns dos seus membros, dizendo à sociedade o quanto o Estado pode ser justo e confiável, como um honorável magistrado. Ao contrário, uma postura de não ter limite, de ser capaz de dizer, como o Secretário do Tesouro americano, Henry Paulson, em 2008, que não poria mais um dólar na salvação do Lehman Brothers e dias depois fazer brotar dos fundos públicos US\$ 700 bilhões para sustentar mais de uma dezena de instituições financeiras em estado falimentar.

Esse Estado tem três novas dimensões: a cessão e prospecção de negócios ao investimento privado, a constituição de associações mercantis contratualizadas em parcerias e o gerenciamento das crises e dos seus desdobramentos administrativos e financeiros. 
A cessão e prospecção de negócios se inicia com a volumosa transferência de ativos e serviços para o setor privado, a título de descentralização, na linguagem das reformas do Estado e do aparelho do Estado. São concessões e privatizações. Mais tarde, a privatização, forma mais forte da descentralização, torna-se um genérico dessas cessões, cuja forma legal é a concessão, mas, agora, a concessão com espírito da contratualização, isto é, não o espírito do "mando autoritário", mas o da "administração pública consensual". Nesse processo se disponibilizam não só os direitos, mas, igualmente, a poupança pública presente nos investimentos que são a base dos serviços - os satélites de comunicação, as usinas hidrelétricas, as instalações hidráulicas e de saneamento, as pontes e estradas, para dar alguns exemplos. Gradativamente, essa nova dimensão do papel do Estado vai se tornando uma tônica da gestão pública, cedendo-se crescente e diversificadamente os espaços de serviços públicos. Mais recentemente, após a cessão dos portos e aeroportos, pelo governo federal, a prefeitura do Rio de Janeiro anuncia a cessão dos túneis, que passariam à administração do setor privado.

As associações mercantis, igualmente contratualizadas, são especialmente ilustradas pelas parcerias públicoprivadas, cuja extensão e alcance são vastos e variados, indo dos presídios e estádios de futebol aos hospitais. Capitais públicos e privados se associam não mais para viabilizar entes públicos, como as sociedades de economia mista, mas para proporcionar negócios privados, na inversão que leva consigo o caráter público de alguns serviços.

Finalmente, o gerenciamento das crises, quando o Estado vai além do refinanciamento, além do perdão de dívidas e obrigações, além dos empréstimos subsidiados. O gerenciamento que faz o Estado é completo, adequado ao que for necessário, inclusive a gestão direta da empresa.

São essas condições que confirmam um novo caráter do Estado. Ele abandona o éthos público, cuidadosamente construído desde Rousseau, para quem interesses públicos e privados não devem coabitar, por uma concepção de parceria irrestrita. A partir de então, essas fronteiras do público e do privado se tornaram móveis, flexíveis e adaptativas. A expressão intervenção do Estado passou à figura do passado e o conceito de que Estado bom é Estado mínimo foi substituído pela convicção de que o Estado bom é o Estado servidor.

\section{Referências}

AGÊNCIA BRASIL. Salvador inaugura primeiro hospital fruto de parceria público-privada. 14 set. 2010. Disponível em: <http://memoria.ebc.com.br/agenciabrasil/noticia/2010-09-13/salvador-inaugura-primeiro-hospital-fruto-deparceria-publico-privada>. Acesso em: 23 fev. 2014.

ARRIGHI, G. O longo século XX. Rio de Janeiro: Contraponto, 1996.

BANCO CENTRAL DO BRASIL - BCB. PROER: Programa de Estímulo à Reestruturação e ao Fortalecimento do Sistema Financeiro Nacional. Disponível em: <https://www.bcb.gov.br/?PROER>. Acesso em: 22 fev. 2014.

BANDEIRA DE MELLO, C. A. Curso de direito administrativo. São Paulo: Malheiros, 2005.

BARAN, P.; SWEEZZY, P. El capital monopolista. Madrid: Siglo XXI, 1982.

BIONDI, A. O Brasil privatizado: um balanço do desmonte do Estado. São Paulo: Perseu Abramo, 2003.

BRASIL. Brasil inovador: o desafio empreendedor - 40 histórias de sucesso de empresas que investem em inovação. Brasília, DF: IEL/NC, 2006.

BRAVERMAN, H. Trabalho e capital monopolista. Rio de Janeiro: Zahar, 1977.

BRESSER-PEREIRA, L. C. Reforma do Estado dos anos 90: lógica e mecanismos de controle. Brasília, DF: MARE, 1997. 
Gestão do setor público: estratégia e estrutura para um novo Estado. In: BRESSER-PEREIRA, L. C.; SPINK,

P. Reforma do Estado e administração pública gerencial. Rio de Janeiro: FGV, 2003. 21-38 p.

CHOMSKI, N.; DIETRICH, H. A sociedade global. Blumenau, SC: Ed. Furb, 1999.

DAGGETT, S. Costs of major U. S. wars. 29 jun. 2010. Disponível em: <http://www.fas.org/sgp/crs/natsec /RS22926.pdf>. Acesso em: 12 jan. 2014.

DRUCKER, P. Inovação e espírito empreendedor: prática e princípios. São Paulo: Pioneira Thompson, 2001.

ESPING-ANDERSEN, G. As três economias políticas do Welfare State. Lua Nova, n. 24, p. 85-116, 1991.

FIORI, J. L. Estado do bem-estar social: padrões e crises. Rio de Janeiro: IMS/UERJ, 1995.

FÓRUM BRASILEIRO DE SEGURANÇA PÚBLICA - FBSP. Anuário brasileiro de segurança pública. 7. ed. São Paulo: FBSP, 2013.

FUNDO MONETÁRIO INTERNACIONAL - FMI. World Economic Outlook. Washington, DC: FMI, 2007 a.

A globalização da mão de obra. Washington, DC: FMI, 2007b.

GIACOMONI, J. Orçamento público. São Paulo: Atlas, 2010.

GOBETTI, S. W.; AMADO, A. M. Ajuste fiscal no Brasil: algumas considerações de caráter pós-keynesiano. Revista de Economia Política, v. 31, n. 1, p. 139-159, 2011.

GRACIOLLI, E. J. Privatização da CSN: da luta de classe à parceria. São Paulo: Expressão Popular, 2007.

GRAMSCI, A. Maquiavel, a política e o Estado moderno. Rio de Janeiro: Civilização Brasileira, 1968.

GROTTI, D. A. M. A experiência brasileira nas concessões de serviço público. Interesse Público, v. 9, n. 42, 2007. Disponível em: <http://bdjur.stj.jus.br/dspace/handle/2011/38544>. Acesso em: 20 fev. 2014.

HARVEY, D. A condição pós-moderna. São Paulo: Loyola, 1994.

. A liberdade da cidade, GEOUSP - Espaço e Tempo, n. 26, p. 9-17, 2009.

HOBSBAWN, E. A era das revoluções. São Paulo: Paz e Terra, 1994.

Era dos extremos. São Paulo: Companhia das Letras, 1995.

HOGAN, M. The Marshall Plan. New York: Cambridge University Press, 1987

JOHNSON, C. MITI and Japanese miracle: the growth of industrial policy - 1925-1975. San Francisco, CA: Stanford University Press, 1982.

JURAN, J. Planejando para a qualidade. São Paulo: Pioneira, 1990.

KALECKI, M. A macrodynamic theory of business cycles. Econometrica, v. 3, n. 3, p. 327-344, 1935.

KEYNES, J. M. Teoria geral do emprego, do juro e do dinheiro. Rio de Janeiro: Fundo de Cultura, 1964.

KURZ, R. O colapso da modernidade. São Paulo: Paz e Terra, 1991.

Uma vida humana? Só sem mercado, Estado e trabalho. 1999. Disponível em: <http://obeco.planetaclix.pt/rkurz54.htm>. Acesso em: 18 fev. 2014. 
LEIVA, O. C. Crítica a la interpretación financiera de la crisis. In: FERNÁNDEZ, D. C.; GANDÁSEGUI HIJO, M. Estados Unidos más allá de la crisis. México, DF: Siglo XXI, 2012. 81-111 p.

LAGEMANN, E.; BORDIN, L. C. V. A tributação nos países do NAFTA (EUA, México e Canadá). Revista Indicadores FEE, v. 23, n. 2, p. 306-374, 1995.

LOSURDO, D. Democracia ou bonapartismo. Rio de Janeiro: Ed. UFRJ/Ed. Unesp, 2004.

MARX, K. As lutas de classes na França. In: MARX, K.; ENGELS, F. Textos. São Paulo: Alfa-Ômega, $1982 a$. v. 3. . Feuerbach. In: Obras escolhidas. Lisboa: Avante! 1982b.

. O capital. São Paulo: Abril, 1985. v. 2.

Grundrisse. São Paulo: Boitempo, 2011.

; ENGELS, F. A ideologia alemã. Lisboa: Presença, [s.d]. v. 2.

Manifesto comunista. In: Textos. São Paulo: Alfa-Ômega, 1982. v. 3.

MONTEIRO, J. V. Maior complexidade institucional e expansão do poder de mando. Rev. Adm. Pública, v. 44, n. 4, p. 1023-1030, 2010.

MONTES, M. El rol de las empresas del Estado en el desarrollo industrial. In: CHAVEZ, D.; TORRES, S. (Eds.). La reinvención del Estado. Amsterdam: Transnational Institute, 2013. 47-58 p.

MUNEVAR, D. El déficit fiscal de Estados Unidos y el futuro del dólar. In: FERNÁNDEZ, D. C.; GANDÁSEGUI HIJO, M. Estados Unidos más allá de la crisis. México, DF: Siglo XXI, 2012. 210-232 p.

O GLOBO. BNDES assina primeiros contratos de parcerias público-privadas. $1^{\circ}$ set. 2008. Disponível em: <http://g1.globo.com/Noticias/Politica/0,,MUL756584-5601,00.html>. Acesso em: 23 fev. 2014.

De hidrelétricas a refinarias e estádios, tá tudo dominado. 8 maio 2011. Disponível em: <noticiaonline2.blogspot.com/2011/.../08-de-maio-de-2011-o-globo.htm>. Acesso em: 23 fev. 2014.

ORGANISATION FOR ECONOMIC CO-OPERATION AND DEVELOPMENT - OCDE. OECD report. Paris: OECD, 1986.

National accounts at a glance. Paris: OECD, 2009.

POLANYI, K. A grande transformação: as origens de nossa época. Rio de Janeiro: Campus, 1980.

PONTIER, J.-M. Les contrats de plan entre l’État et les régions. Paris: PUF, 1998.

PRADO JR. C. A revolução brasileira. São Paulo: Editora Brasiliense, 1987.

SAPPINGTON, D.; STIGLITZ, J. Privatization, information and incentives. Journal of Policy Analysis and Management, v. 6, n. 4, p. 567-582, 1987.

SCHUMPETER, J. A teoria do desenvolvimento econômico. São Paulo: Abril Cultural, 1982.

SILVA FILHO, E.; FRACALOSSI DE MORAES, R. Dos “dividendos da paz" à guerra contra o terror: gastos militares mundiais nas duas décadas após o fim da Guerra Fria - 1991-2009. Brasília, DF: Ipea, 2012.

SIMONSEN, M. H. A conta-corrente do governo: 1970/1988. Rio de Janeiro: Fundação Getulio Vargas, 1989. (Ensaios Econômicos, n. 136). 
SKYSCRAPERCITY. Contratos com o BNDES garantem investimentos de quase 300 milhões em mobilidade urbana e saneamento, 2010. Disponível em: <http://www.es.gov.br/Noticias/119386/detalhes.htm>. Acesso em: 23 fev. 2014.

TANZI, V.; SCHUKNECHT, L. Public spending in the $\mathbf{2 0}^{\text {th }}$ century: a global perspective. New York: Cambridge University Press, 2000.

THE NEW YORK TIMES. Treasury hires Perella Weinberg to advise on Ally IPO, 2011. Disponível em: <dealbook.nytimes.com/.../treasury-hires-perella-weinberg>. Acesso em: 22 fev. 2014.

THE WALL STREet JOURNAL. Perella Weinberg advises on health of bond insurers, 2011. Disponível em: <http://online.wsj.com/news/articles/SB120154767610322973>. Acesso em: 22 fev. 2014.

TITMUS, R. Essays on the Welfare State. London: Allen \& Unwin, 1963.

TOFFLER, A. A empresa flexível. Rio de Janeiro: Record, 1985.

WASHINGTON POST. BP agrees to \$ 20 billion fund for gulf oil spill claims. 17 jun. 2010. Disponível em: <http://www.washingtonpost.com/wp-dyn/content/article/2010/06/16/AR2010061602614.html>. Acesso em: 22 fev. 2014.

WORLD HEALTH ORGANIZATION - WHO. World health statistic 2013. Genebra: WHO, 2013. 